\title{
THE GOTHIC NOVEL CURIAL E GÜELFA: AN ERUDITE CREATION BY MILÀ I FONTANALS
}

\author{
Rosa NAVARro \\ Universitat DE BARCELONA \\ SPAIN
}

Date of receipt: $27^{\text {th }}$ of January, 2014

Final date of acceptance: $18^{\text {th }}$ of March, 2015

\section{Abstract}

Curial e Güelfa is not a chivalric novel written in the $15^{\text {th }}$ century, but a 'Gothic' novel written in the $19^{\text {th }}$ century by its professed discoverer, Manuel Milà i Fontanals. The text reveals a clear portrait of its author: an erudite scholar who had read vastly, from Muntaner's Crònica to Il Novellino, from Paris e Viana to Petit Jehan de Saintré; someone familiar with the troubadours Rigaut de Berbezilh and Raimbaut de Vaqueiras; an author who had read, among many other works, Fulgentius' Mitologiae and Enrique de Villena's Glosas de la Eneida; Alfonso de la Torre's Visión deleitable, Manrique's Verses and El cortesano by Luis Milán. The concordances with these works make it evident that the book is a composite imitation by the highly erudite Catalan writer. Moreover, they attest to the fact that Curial e Güelfa can by no means have been written in the $15^{\text {th }}$ century, as no writer could have had all the aforementioned works at his disposal at the time, and it was naturally impossible to read books published after the alleged date of writing of Curial e Güelfa.

\section{KEYWORDS}

Literary forgery, Composite imitation, Gothic novel, Traces of reading, Creative erudition.

\section{Capitalia Verba}

Falsificatio litteraria, Imitatio composite, Fabula Gothica, Lecturae vestigial, Eruditio creatrix. 


\section{Introduction}

There is a long history of erudite forgeries that includes many illustrious actors, such as Erasmus. In his classic Forgers and Critics, Anthony Grafton notes that:

In 1530, Erasmus published his fourth edition of the works of Saint Cyprian. This included as a stop-press supplement a treatise, De duplici martyrio (On the Two Forms of Martyrdom), which, as its table of contents said, was "discovered in an ancient library; may it be possible to search out other valuable works of his as well" [...]. De duplici martyrio was not Erasmus' discovery but his composition; it marks an effort to find the support of the early Church for his theology at the cost - which he elsewhere insisted must never be paid — of falsifying the records of that Church. The greatest patristic scholar of the sixteenth century forged a major patristic work. ${ }^{1}$

It took a humanist like Erasmus to create such a forged work, as only the greatest scholar on patristics could compose a convincing falsification. He was given away by how the text - his text - supported his own ideological positions, but this was precisely the point. Grafton affirms, "in the seventeenth, eighteenth, and nineteenth centuries all these practices continued", with the falsification of texts in Romance languages adding to the forgeries of classical texts:

In the eighteenth, Thomas Chatterton and James Macpherson used the traditional means -imposition of supposedly archaic script and spelling on the one hand, the claim to have translated from inaccessible originals in an unknown language on the other- to reimagine the medieval and the premedieval history of the Gothic North itself [...]. And even sophisticated reading publics, like the early readers of Horace Walpole's Castle of Otranto, a Gothic thriller supposedly reprinted from a black-letter original text in the library of an English recusant family, were fooled, perhaps not without complicity, by the convention. No form of serious forgery has ever entirely died. The artistic creation of supposedly historical documents has continued into the nineteenth and twentieth centuries. ${ }^{2}$

This is the context of a Catalan novel which, though credited in all histories of literature as a $15^{\text {th }}$ century work, was in reality a literary creation of the person who discovered it, the extraordinary scholar Manuel Milà i Fontanals. As with Erasmus and his De duplici martyrio, only such a great scholar of Romanesque literature as Milà could write a novel like Curial e Güelfa, which weaves together Catalan, Castilian, Provencal, French and Italian texts.

1. Grafton, Anthony. Forgers and Critics. Creativity and Duplicity in Western Scholarship. London: Collins \& Brown, 1990: 44-45.

2. Grafton, Anthony. Forgers and Critics...: 32, 34. 


\section{The discovery of Curial e Güelfa}

Curial e Güelfa is a strange mixture of chivalric romance and sentimental novel that includes both mythological and allegorical passages. Its discoverer, Manuel Milà i Fontanals, described it as a singulier mélange de gothique et de renaissance ("strange mixture of gothic and renaissance"). After centuries of supposed total neglect and oblivion, the only manuscript including the novel appeared in the $19^{\text {th }}$ century. In 1876, Milà i Fontanals published Notes sur trois manuscrits in Revue de Langues Romanes. ${ }^{3}$ In section II, Un roman catalan, Milà tells the story (quite fantastic in itself) of how the director of the National Library, Agustín Durán (who had passed away in 1862, quite a long time before this article was published) knew about the novel dans ces dernières années ("in his last years") and wrote a description, which Milà includes in his article translated in French:

Ce livre, ou chronique chevaleresque, sans titre, parle des prouesses de Curial et de ces [sic] amours avec la noble dame Güelfa. C'est un précieux Codex, à ce qu'il paraît inédit, écrit en langue catalane. À en juger per [sic] ses lettres, sa dimension, ses marques, sa qualité de papier et même par sa reliure, il paraît avoir été écrit ou copié pendant la première moitié $d u$ $X V$ e siècle. Il est divisé en trois libres. ${ }^{4}$

As I argued in another work, it is surprising that a great erudite scholar like Milà admits that the c'est un précieux 'Codex', à ce qu'il paraît inèdit: ${ }^{5}$ his cautionary tone is just not credible. He continues:

Le langage du roman nous ferait croire à une époque un peu plus moderne; mais nous l'avons trop peu étudié pour en déduire s'il fut antérieur ou postérieur au Tirant lo Blanch, le seul roman chevaleresque de longue haleine qu'on connaisse dans la littérature catalane [...] Le langage de notre roman est élégant et correct, et son orthographe assez régulière. Nous remarquons quelques prét[érites] en ba pour ua-va. ${ }^{6}$

3. Milà i Fontanals, Manuel. "Notes sur trois manuscrits". Revue de Langues Romanes, 10 (1876): 233-238. 4. "This book, or chivalric chronicle, untitled, talks about the exploits of Curial and of his loves with the noble lady Güelfa. It is a precious codex which seems unpublished and written in Catalan. According to its fonts, size, marks, paper quality and even bookbinding, it seems to have been written or copied in the first half of the $15^{\text {th }}$ century. It is divided into three books". Milà i Fontanals, Manuel. Estudios sobre Historia, Lengua y Literatura de Cataluña. Obras completas, ed. Marcelino Menéndez Pelayo. Barcelona: Librería de Álvaro Verdaguer, 1890: III, 486.

5. "this is a precious codex, which seems unpublished". Milà i Fontanals, Manuel. "Notes sur trois...": 233.

6. "The language of the novel makes us believe in slightly more modern times; but we have studied too little to deduce whether it was before or after the Tirant lo Blanch, the only lengthy chivalric novel we know in Catalan literature [...]. The language of our novel is elegant and proper and its spelling, fairly regular. We note some past tenses in 'ba' instead of 'ua'-'va'”. Milà i Fontanals, Manuel. Estudios sobre Historia, Lengua y Literatura de Cataluña...: III, 486. 
The book's language seems to take us to a more modern period; it is qualified as elegant and correct, and the orthography, as assez régulière ("quite regular"). Then, the author notes a bizarre detail: that some past tenses end in -ba (the present day termination in Spanish) instead than -va (the modern form in Catalan). But why was such trait referred to in describing a codex written before graphic standardisation? It is not a matter of doubting the great ability of the scholar, but rather, I would argue that by noting this, Milà was giving a hint of something else.

According to Durán, the codex seemed to have been copied in the first half of the $15^{\text {th }}$ century, but the extremely erudite Milà i Fontanals notes that it is not possible to know if the work dates from before or after Tirant, the writing of which, according to Joanot Martorell, started in $2^{\text {nd }}$ January, 1460. Even though Milà says he hardly know anything about the novel, he summarised its content and reproduced some fragments. What is more, this admirable scholar, a father of the Renaixença, bumps into a jewel like Curial e Güelfa, a book that so enriches medieval Catalan literature, and decides not to edit and diffuse it! ${ }^{7}$ The novel would not be published until 1901 by Antonio Rubió i Lluch. In 1991, Jaume Riera i Sans provided an explanation for this anomalous situation: Curial e Güelfa was a forgery authored by its supposed discoverer: Manuel Milà i Fontanals. ${ }^{8}$ All scholars rejected his proposal. ${ }^{9}$

Riera i Sans pointed at strange elements in the codex, such as the two first quires (Quaderno primero, Segundo) having signature marks in Spanish in the same hand that wrote the text. He also mentioned the fact, that in a warning about the text's punctuation (which greatly facilitates its reading) Ramon Aramon i Serra, ${ }^{10}$ qualified it as 'logical', and correcting himself, 'modern': Més que puntuació lògica, es

7. In a letter from the $3^{\text {rd }}$ October 1876 written to Menéndez Pelayo, Milà writes: En mi reciente ida a Madrid vi en la Biblioteca Nacional una traducción de la Disciplina clericalis de Pedro Alfonso, que se ha dado como traducción catalana y que yo creo que es gascona y acaso bearnesa. Ya le cursaré a V. una notita que imprimo en la Revue des Langues Romanes, acerca de este y otros dos manuscritos ("In my recent trip to Madrid to the National Library I saw a translation of the 'Disciplina clericalis' by Pedro Alfonso, which has been explained as a Catalan translation, although I think it's Gascon or perhaps Bearnaise. I will still send you a small article that I am publishing in the 'Revue des Langues Romanes', about this and two other manuscripts"). He does not even mention Curial, which is one of the otros dos manuscritos! ("two other manuscripts"). Milà i Fontanals, Manuel. Epistolari, correspondència recollida i anotada per L. Nicolau d'Olwer. Barcelona: Institut d'Estudis Catalans, 1932: II (1875-1880), 100.

8. Riera i Sans, Jaume. "Falsos dels segles XIII, XIV i XV". Actes del novè col-loqui internacional de Llengua $i$ Literatura catalanes (Alacant/Elx, 9-14 de setembre de 1991). Barcelona: Publicacions de l'Abadia de Montserrat, 1993: 479-489.

9. Riera i Sans' opinion was immediately refuted by practically all the experts in different aspects of the subject. This refutation was based on the literary format, the language and vocabulary used and formal aspects like the spelling and binding. Among others, in this line the following works are notable: Perarnau, Josep. "El manuscrit medieval del 'Curial e Güelfa'”. Arxiu de Textos Catalans Antics, 11 (1992): 363-373; Hernández, Carmen; Ruiz de Elvira, Isabel. "Estudio sobre la encuadernación del ms/9750 de la biblioteca Nacional de Madrid: “Curial e Güelfa'”. Arxiu de Textos Catalans Antics, 11 (1992): 373377; Colon, Germà. “Una altra vegada 'atovar' en el 'Curial e Güelfa'”. Arxiu de Textos Catalans Antics, 11 (1992): 378-384; Gimeno, Francisco M. "Notes d'un paleògraf a propòsit del matritensis 9750 de la Biblioteca Nacional (Curial e Guelfa)". Caplletra, 15 (1993): 75-87. Our study does not aim to argue with these contributions but make formal and literary arguments so far unpublished that can not be ignored. 10. Curial e Güelfa, ed. Ramon Aramon i Serra. Barcelona: Barcino, 1930, 3 vols. All citations are of this edition, I indicate volume and page. 
tracta d'una puntuació moderna, no per altra raó sinó perquè el copista hi passava en net un text que ja tenia els punts $i$ comes posats a la manera actual. ${ }^{11}$

However, there is something more in the codex that indicates its 'modern Gothic' nature: the presence of the pencil. The guidelines are drawn in pencil. This can be seen perfectly at least from $52 \mathrm{v}$. to 125 , where this disappears, and it is also very clear on some folios (for example, on 68, 73, 74, 81, 85 v., 102, etc.). Furthermore, together with the regular numbering of the text in pencil by a librarian, there is another sporadic, but correct, one also in pencil, that does not coincide with the former because it begins two folios before (it counts the two blank folios that precede the start of the text). Thus, we can see the following numbers in pencil: $36,50,81,100,111,137,171,172,173,185,191,197,200$ and 228. The last is on the second blank folio after the end of the text and closes the codex. As is logical, this sporadic numbering, organised (always indicating two folios more than the 'oficial' numbering), was done before the codex was numbered by a professional. What is the sense of only numbering these solo pages? Who could have done so? These questions are essential for the material used: the pencil, an invention that only began to be used at the end of the $18^{\text {th }}$ century and then more generally, in the $19^{\text {th }}$. This numbering only makes sense for the person who did it; and it would not be a supposed reader, but rather the person who was copying the text and counting the work he had done. Regarding the codex, in his edition of the Curial, Badia and Torró summarised that:

Perarnau $i$ Gimeno daten respectivament la lletra entre 1430-1440 i 1412-1465, tot posantla en relació amb la d'altres còdexs $i$ documents coetanis de mà catalana, propers a les oficines del mestre racional, mentre que Hernández $\theta$ Ruiz estimen que el relligat del volumen és de darreries del XV o principis del XVI. ${ }^{12}$

The binding is undoubtedly old. When it was restored, it was found to contain some fragments of text that seem to be the papers of some scribes' office and are written in Castilian (not in Catalan). However, it is logical that if one wants to play at making medieval manuscript, one gives it an adequate external form. The paper dates from that time, but there are over ten different watermarks in the folios, as if old papers had been collected to write the text on. I trust that modern methods of chemical analysis of the ink and paper will be used so that the material analysis of the codex confirms what the contents of the work copied in it state. I am positive

\footnotetext{
11. "More than logic punctuation, it is a modern punctuation, for no other reason than the copyist was writing a clean copy of a text that already had the full stops and commas according to current mode". Riera i Sans, Jaume. "Falsos dels segles XIII, XIV i XV...": 480.

12. "Perarnau and Gimeno respectively date the writing between 1430-1440 and 1412-1465, relating it to that of other codices and contemporary documents written in Catalan, close to the offices of the general auditor of the Crown of Aragon (mestre racional), while Hernández and Ruiz estimate that the stitching of the volume is from the end of the 15th or early 16th century". Badia, Lola; Torró, Jaume. "Introducció", Curial e Güelfa. Barcelona: Quaderns Crema, 2011: 11.
} 
that Riera i Sans is right: Curial e Güelfa is a historical novel from the $19^{\text {th }}$ century and not a chivalric novel from the $15^{\text {th }}$ century.

\section{Critical contributions about the author of the Curial}

In the preliminary note to his 1939 edition, Aramon i Serra dates the work from vers la meitat del segle $X V$ ("towards the middle of the $15^{\text {th }}$ century"), and bases this on the fact that Rubió $i$ Lluch $i$ Alfons Par han arribat, per camins distints, a concretar-la entre els anys $1443 i$ 1460. He stresses the great erudition of the author:

Dant hi és recordat tothora amb veneració $i$ les seves citacions són ben abundoses; elles fan de Curial e Güelfa l'obra més dantesca de la nostra literatura. Boccacio [...] és també una font important del Curial. El Novellino proporciona a l'autor la base de l'acció principal, almenys per al segon i tercer llibres. No és possible d'oblidar, altrament, els herois del cicle bretó $i$ altres personatges vivents en la literatura francesa; ni els autors clàssics $i$ totes les al-lusiones mitològiques; ni l'episodi del cor menjat, evocador de la vida llegendària del trobador Guillem de Cabestany, i la cançó de Richart de Barbezilh, que indiquen uns contactes amb la literatura provençal; ni les continues referències a Guido delle Colonne. ${ }^{13}$

He also emphasises that l'erudició, usada com a motiu de llüment, l'abús de cites mitològiques, són els excessos dels que es lliuraven —amb una exageració evident-als corrents nous, ${ }^{14}$ in other words, the Renaissance. Thus, we have before us a work written in the mid $15^{\text {th }}$ century, but whose author uses compound imitation -of various literatures - like a Renaissance bee, and does so before printing could have given him access to the numerous works from various literatures that are imitated or cited in his.

Martí de Riquer dates the work between 1435 and 1462, and on talking about the profile of the author of the Curial, he highlights some surprising modernities in the work:

No sabem res de l'autor del Curial (potser un urgellista nostàlgic), excepte que era un hàbil escriptor i un elegant prosista [...] i fins s'atreveix amb audàcies, com aquella mena de cas

13. "Rubió i Lluch and Alfons Par have reached by different paths to accomplish it between the years 1443 and 1460"; "Dante is always remembered with veneration and his citations are abundant; they make Curial e Güelfa the most Dantescan work in our literature. Boccacio [...] is also an important source for the Curial. The Novellino provides the author with the basis for the principal action, at least for the second and third books. Otherwise, it is not possible to forget the heroes of the Breton cycle and other living characters of French literature; nor the classical authors and all the mythological allusions; nor the episode of the eaten heart, evoking the legendary life of the troubadour Guillem de Cabestany, and the song of Richart de Barbezilh, that indicate contacts with Provencal literature; nor the frequent references to Guido delle Colonne". Aramon i Serra, Ramon. "Notícia preliminar", Curial e Güelfa. Barcelona: Barcino, 1930: I, 7, 11-12.

14. "erudition, used as a motif to stand out, the abuse of mythological citations, are the excesses of those who gave themselves -with evident exaggeration- to the new trends". Aramon i Serra, Ramon. "Noticia preliminar...": I, 13. 
de telepatia que s'esdevé quan Curial, després de vèncer els acusadors de la duquessa, veu un retaule de Sant Marc i es recorda de la Güelfa, i a aquesta, en el mateix moment, però a Monferrato, se li apareix Sant Marc i li anuncia la victòria del cavaller a tan llunyanes terres. El Curial és dividit en tres llibres, i o bé es tracta d'una imperdonable distracció o bé d'una audàcia digna d'Unamuno o de Pirandello que, al tercer llibre, Melchior del Pando digui a Curial, parlant-li en estil directe: "E faç conclusió que millor partit te'n portes que no leixes a la Güelfa, segons en l'altre libre et diguí. ${ }^{15}$

The great scholar was surprised by the audacity of the telepathy between the main characters, and the narrator's awareness - and memory - of the structure he gave to the work with the likewise 'modern' reference to what was stated in the previous book.

I must also add to these 'modernities' another: a phrase that Güelfa says to the Abbess about the destierro she imposes on Curial: Lo món és gran e ample. ${ }^{16}$ We hear that the "the world is broad and wide" in Shakespeare's tragedy of Romeo and Juliet. This is what Friar Lorenzo tells Romeo to console him for his banishment, "Hence from Verona art thou banished. I Be patient, for the world is broad and wide"; in scene III of the third act. ${ }^{17}$

In the extensive introduction to the work by Badia and Torró in his edition, the scholars emphasise his meticulous construction:

El Curial és una obra planificada amb cura, que té ben poc a veure amb una novel-la que es va engreixant a cop d'inventiva, penjant episodis d'un fil, com passa sovint al Tirant lo Blanc. Van ser calculades la mesura de les dimensions, la divisió en llibres, la reiteració de motius simbòlics i la cronologia interna. Cada una de les parts del Curial va encapçalada per un pròleg que indica l'abast temàtic $i$ moral de la ficció. ${ }^{18}$

15. "We know nothing about the author of the Curial (perhaps a nostalgic Urgellist), except that he was a talented writer and an elegant prosaist [...] and even dared with audacities, like that kind of case of telepathy that happens when, after defeating the duchess' accusers, Curial sees an altarpiece of Saint Mark and is reminded of Güelfa, and she, at the same moment, but in Monferrato, sees Saint Mark before her and he announces the knight's victory in lands so distant. The Curial is divided into three books, and it is either an unpardonable distraction or an audacity worthy of Unamuno or Pirandello that, in the third book, Melchior del Pando, talking to Curial directly, says 'And I reached the conclusion that you take the best part if you don't give up the 'Güelfa, as it is stated in the other book'". Riquer, Martí de. Literatura catalana medieval. Barcelona: Ajuntament de Barcelona, 1972: 109.

16. "exile"; "the world is big and wide". Curial e Güelfa...: III, 170.

17. Shakespeare, William. Romeo and Juliet. Madrid: Cátedra, 2000: 292.

18. "The Curial is a carefully planned work, one that has little to do with a novel that grows by blows of imagination, with episodes hanging by a thread, as happens often in Tirant lo Blanc. The measure of the dimensions, the division onto books, the reiteration of symbolic motifs and the internal chronology were calculated. Each of the parts of the Curial is headed by a prologue that indicates the thematic and moral scope of the fiction". Badia, Lola; Torró, Jaume. "Introducció...": 19. 
The scholars, on presenting the criteria for their edition, state that the prose in the story: El Curial és escrit en una prosa treballada, clara i elegant, comprensible des del català literari actual. ${ }^{19}$ And regarding the dating, they state that,

La segona meitat de la dècada dels anys quaranta del segle XV, quan Alfons IV el Magnànim s'acabava d'instal-lar al tron de Nàpols (1442), podria escaure a la redacció del Curial, d'acord també amb el tracte benvolent que reben les grans cases nobles de França $i$ dels Països Baixos, com els Anjou, els Orleans i els Borgonya, que s'havien enfrontat en la Guerra dels Cent Anys a la primera meitat del segle i que majoritàriament havien estat enemigues d'Alfons [...]. La muller del marquès de Montferrat es diu Andrea, nom de fonts que a Itàlia és masculí. ${ }^{20}$

In 2011, I published the first results of my research in Clarín. I signaled Joanot Martorell's Tirant lo Blanc as the main source for Curial and, by noting a connection between Petit Jean de Saintré and a song by Rigaut de Berbezilh, sketched the narrative scheme underpinning the work. I also listed traces of reading in Curial from $\mathrm{La}$ Celestina, La vida de Lazarillo de Tormes, El cortesano by the Valencian author, Luis Milán, Cervantes' El ingenioso hidalgo don Quijote de la Mancha and Novelas ejemplares, and Relaciones de la vida del escudero Marcos de Obregón. ${ }^{21}$ I will leave the analysis of the presence of Quijote and, especially, of Tirant lo Blanc in Curial for another occasion. As it should be obvious that a $15^{\text {th }}$ century work could not show clear distinctive concordances with works written after it, these traces of reading prove that the writer of Curial had not only read these texts, but that he was also a highly erudite scholar of Romanesque literature.

In addition to traces of texts written after the $15^{\text {th }}$ century (to which I later included Walter Scott's novels), ${ }^{22}$ it is the novel's very literary concept, as a work of composite imitation, that gives away its great author, the erudite scholar Milà i Fontanals. Below, I analyse the structure of the novel to emphasise its merits. First, however, I would like to introduce a historical character, a contemporary of Milà by a few years, a General who played a role in the occupation of Barcelona by the Hundred Thousand Sons of Saint Louis (1823) and whose name was no other than Curial.

19. "The Curial is written in crafted, clear and elegant prose, understandable from current Catalan literature". Badia, Lola; Torró, Jaume. "Introducció...": 111.

20. "The second half of the 1440s, when Alfonso IV the Magnanimous had just taken the throne of Naples (1442), could be applicable for the writing Curial, in line also with the benevolent treatment received by the great noble houses of France and those of the Low Countries, like those of Anjou, Orleans and Burgundy, who had faced each other in the Hundred Year's War in the first half of the century and who had mainly been enemies of Alfonso". However, a little later, they themselves highlighted a contradiction with the Italian setting, because "the wife of the Marquis of Montferrat is called Andrea, a name that is masculine in Italy". Badia, Lola; Torró, Jaume. "Introducció...": 43, 46.

21. Navarro, Rosa. “Misterios en una extraña novela: “Curial e Güelfa'”. Clarín, 96 (2011): 3-11.

22. Navarro, Rosa. "'Curial e Güelfa', 'mélange de gothique et de Renaissance'”, El texto infinito. Tradición y reescritura en la Edad Media y el Renacimiento, Cesc Esteve, ed. Salamanca: Sociedad de Estudios Medievales y Renacentistas, 2014: 191-225. 


\section{General Curial and the Fifth Division in Catalonia}

Curial's name can be read on the east pillar of the Arc de Triomphe in the Avenue des Champs-Élysées in Paris, as he was one of Napoleon's generals. Philibert-JeanBaptiste-François Curial was born in April $21^{\text {st }}, 1774$ in Saint-Pierre-d'Albigny, in the region of Savoy, which was then Italian. His paternal grandfather was a peasant, and the maternal grandfather a lawyer. Curial's father, also a lawyer, sided with the French when their troops invaded Savoy in 1792 and his two sons joined the army: one of them, our Curial, reached the highest military honours for heroism in numerous battles. He fought in as many territories as the Emperor, from Egypt to Russia, and of course, in Spain as well as Jena, Eylau, Essling, Wagra. In 1814, Napoleon named him Count of the Empire. However, Curial bade his time when the Emperor faced disgrace, and when Louis XVIII restored the monarchy, he pledged allegiance to the Bourbons. Napoleon's return from Elba interrupted his promotion and he had to wait for the Bourbon restoration to regain his appointments and obtain new honours. These included member of the Chamber of Peers, gentlemanin-waiting of the King, First Chamberlain, Maître de la Garde-Robe, Knight of the Orders of the Holy Spirit and Saint Michael, Grand Cross of the Legion of Honor, Knight Commander of Saint Louis, Grand Cross of the Order of Saint Ferdinand.

His health and career started to decline after an accident that occurred during the trip to Reims to attend the coronation of the new (and Ultra-royalist) King Charles $\mathrm{X}$ in May 1825. When the horses of the royal carriage bolted, the coach that Curial and three other nobles were riding in ran after it and, although they managed to brake the horses, the coach fell into a ditch. As a consequence, and in addition to two sunken ribs, a bullet he had got in an African battle and that had stopped in his chest apparently moved dangerously close his heart. He never recovered from the accident, but still managed to be posted to Saint-Omer with the prestigious rank of Directeur du Camp. He passed away on May 30 1829.

The General participated in the war in Catalonia in 1823, when the Hundred Thousand Sons of Saint Louis (the French troops sent by Louis XVIII to help Ferdinand VII against the liberals and defenders of the Cadiz Constitution) entered Spain. The Duke of Angoulême, the later Charles X, led the French army. The invading troops were under the command of Marshal Moncey, Duke of Conegliano, and the Fifth division was led by general Curial, after whom the division took its name: 'Curial's division'.

The newspaper Gaceta de Madrid provides details about the military operations by the General, who had been in Spain before under Napoleon and was now serving the Bourbons. A story published on June $1^{\text {st }} 1823$, states that el día 24 de mayo a las dos de la mañana, las tropas de la quinta división, mandadas por el teniente general conde Curial, han sido atacadas en Mataró por los generales revolucionarios Milans y Llovera. As a result:

la quinta división no ha perdido más que tres hombres muertos y ha tenido quince heridos. El teniente general conde Curial hace el mayor elogio del valor con que las tropas de S. M. 
han sostenido el honor de nuestras armas. El resultado de este acontecimiento ha desanimado enteramente el partido revolucionario que hay en Barcelona. ${ }^{23}$

A communiqué in which Marshal Moncey announced victory over the enemy in Molins de Rei (of strategic importance for the Barcelona campaign because of its bridge over the river) to the Minister of War was published on July $19^{\text {th }}$. In it, General Curial is again presented as the one who obtained the victory and established a blockade of Barcelona: Mientras la división Curial ejecutaba las operaciones de bloqueo, ha hecho el enemigo una salida en dos columnas, la una por Monjuí y la otra por Barcelona. And at midnight on July $7^{\text {th }}$, Marshal Duke of Conegliano told the Secretary of State of War: Monseñor: El movimiento sobre Barcelona de la quinta y décima división comenzará mañana 8 de julio. ${ }^{24}$

In 1835, the translation of Memorias sobre la guerra de Cataluña, en los años 1822 y 1823 by Florencio Galli, edecán del general Mina was published in Barcelona. In it, Galli, from his privileged perspective on the opposing side (the Constitutional troops lead by Espoz y Mina) narrates their defeat in Catalonia. His chronicle ends with the capitulación de Barcelona:

Ya no existía nuestro ejército más que en el nombre, mientras se aumentaba extraordinariamente el de los enemigos. Sujetado el Aragón, pudieron las tropas del mariscal Lauriston acercarse a las de Moncey y no formar con estas, por decirlo así, más que un solo cuerpo [...]. Sosteniase en verdad vigorosamente Barcelona, y hostigábase a sus sitiadores con no interrumpidas salidas.

As their troops could not hold out, a surrender was signed, and Tarragona $y$ Hostalrich siguieron la suerte de Barcelona. ${ }^{25}$ General Curial's Fifth division was an important actor in all these operations.

As mentioned before, he would not have much more time after that to act in theatres of war or obtain more honors and appointments. In addition to the Arc de

\footnotetext{
23. "on 24 May at two o'clock, the troops of the fifth division, commanded by Lieutenant General Count Curial, were attacked in Mataro by revolutionary generals Milans and Llovera"; "the fifth division lost only three killed and fifteen wounded. Lieutenant General Count Curial highly praised the courage with which the troops of Your Highness maintained the honour of our arms. The result of this event has entirely discouraged the revolutionary party, which is in Barcelona". Navarro, Rosa. "El general Curial y la literatura". Clarín, 108 (2013): 9.

24. "While the Curial division was executing blocking operations, the enemy made an incursion in two columns, one throughout Monjuic and the other by Barcelona"; "My Lord, the movement towards Barcelona by the fifth and tenth divisions will begin tomorrow, July $8^{\text {th" }}$. Navarro, Rosa. "El general Curial...": 9.

25. "aide-de-camp of General Mina"; "Capitulation of Barcelona"; "Our army was one no more than in name, while the enemies were dramatically increasing. Having taken Aragon, the troops under Marshal Lauriston could approach those of Moncey and form with these, not more than a single body, as we can say [...]. Barcelona resisted vigorously, and the besiegers suffered from frequent incursions from the city"; "Tarragona and Hostalric following the way of Barcelona". Llovera Galli, Florencio. Memorias sobre la guerra de Cataluña, en los años 1822 y 1823. Barcelona: Imprenta de A. Bergnes, 1835: 240-243.
} 
Triomphe in Paris, his name coincides with the main character of Curial e Güelfa. Below, I analyse the structure of the novel.

\section{The narrative structure and origins of Curial e Güelfa}

The leading couple in Curial is modeled after La dame des Belles-Cousines and her young, brave and handsome protégé, Petit Jehan de Saintré, the main characters in the tale by Antoine de la Sale named after its hero and which the author dedicated to Jean d'Anjou, Duke of Calabria and Lorraine, in 1459. The Catalan novel is a love story, but it is also the story of Curial's transformation from a handsome teenager into a brave and famous errant knight. His education in knighthood is possible thanks to Güelfa, the beautiful, rich young widow of the Duke of Milan, sister of the marquis of Montferrat, who falls in love with Curial and becomes his protectress, giving him money through her advisor, Melchior de Pando. This is the main loan from Petit Jehan de Saintré, in which the name of the lady is not revealed (she is only designated by her royal lineage), mais de son nom et signourie l'istoire s'en taist, à cause de ce que cy apres purrez veoir et oyr. ${ }^{26}$ Her role is played by Güelfa (which is not a proper name of a lady) who intelligently directs the courtly education, studies and battle training of the handsome adolescent until he becomes the most famous errant knight. Most of all, she continuously gives him money, which is minutely detailed: gowns, jewels and food are very present in Curial, a feature it shares with French novels, even more than with Tirant.

The two love stories begin in very similarly. In Antoine de la Sale's novel, the beautiful young widow, who does not want to remarry, decides que vraiement elle vouloit en ce monde faire d'aucun jeune chevalier ou escuyer ung renommé homme; she observes the custom and circumstances of all the young boys in court, mais à la parfin sur le petit Saintré s'arresta. Who is this little Saintré? The elder son of lord Saintré from Touraine, who, at thirteen, is serving the king of France as a page, and who sticks out among the rest for his riding, singing, dancing, jouer à la paume, running, and jumping, gaining the highest esteem from the king and queen, lords, ladies and the rest of the people. It is just natural, then, that the dame des BellesCousines notices him. ${ }^{27}$

Güelfa is the young widow of the Duke of Milan, whom she had married at the age of thirteen. Two years later, when her husband dies, she finds herself rich and Duchess of Milan, as well as victim of her youth, as the narrator tells us: no podent resistir als naturals apetits de la carn, qui ab continuus punyiments incessantment

26. "nevertheless, the story tells nothing about her name and lordship, because of the reason you could after see and hear here". La Sale, Antoine de. Le Petit Jehan de Saintré. Paris: La Renaissance du Livre, 1911: 13 .

27. "the thing she most wished in the world is to transform some young knight or squire into a famous man"; "nevertheless, she stopped over the little Saintré". La Sale, Antoine de. Le Petit Jehan de Saintré...: 13. 
la combatien; ${ }^{28}$ she thus reckons, si per ventura ella amàs secretament algun valerós jove, puys que algun no se'n apercebés no seria desonestat. ${ }^{29}$ Remember that secrecy was the key to the love affair between the dame and Petit Jehan. Güelfa examines all those who served in the house of her brother, the Marquis of Montferrat, and chooses handsome Curial, molt savi segons la sua edat, pensà que seria valent home si hagués ab què. The marquis' page has the same qualities as Petit Jehan: bell cantador, e après sonar esturments (de què devench molt famós), axi mateix cavalcar, trobar, dançar, júnyer. ${ }^{30}$ In both stories, the good looks of the young boy compensate for his humble origins, and the lady's money enables him to attain knighthood and fame. They even share a detail: the young boy plays ball (jeux de paume) in front of the palace when he is not in tournaments and the lady looks down at him all the time: Curial tot lo jorn jugava pilota davant lo palau e era per ella continuamente mirat e vist. ${ }^{31}$ This is not a rubber ball (which had then yet to be invented) but the ball of jeux de paume; the first time the dame talks to Petit Jehan, he is watching some players: trouva le petit Saintré là, qui regardoit bas en la court les joueurs de paulmes jouer. ${ }^{32}$

Madame gives him money for his education in morality and knighthood. Their secret love affair lasts sixteen years, and she always wants to be in charge of their courtly love game. When single-handedly he decides to leave the court to pursue the great deeds of a knight, she is really upset, and only forgets him, and assuages her solitude, when she finds a new lover, a hefty country abbot.

The novel of Ghismonda and Giscardo (Decameron, IV, 1), cited in Curial, shares with these two tales the basic scheme: a beautiful young widow who, driven by her concupiscible disidero, seeks a youngster worthy of her love among the palace servants. She choses handsome Giscardo, who is humble, yet full of qualities. The difference is that Ghismonda depends on her father, Prince Tancredo, whereas the dame and Güelfa are wealthy and free women, which enables them to choose the young page but also makes it possible for him to become a famous errant knight. In addition, the tragic ending of Boccaccio's novel (the lover's heart is served to the lady as food) provides material for a dream of Curial: ${ }^{33}$ as it is the lady herself who

28. "given that she cannot resist the natural desire of the flesh, which she combated by incessantly pricking herself". Curial e Güelfa...: I, 26. Desire is very well described in a similar way in a religious text, Mirall dels divinals assots, by Pere Martínez: Lo glorios Sant Pau, tement aquest lligam que entr.ells dos [lo cors i la carn] es, e conexent les temptacions e punyiments espessos de la carn... ("The glorious Saint Paul, knowing the link between both [the flesh and the soul], and knowing the temptations and the pricks from the flesh..."). Martínez, Pero. Obras, ed. Martí de Riquer. Barcelona: Universidad de Barcelona, 1946: 37.

29. "if she secretly loved some brave youth, it would not be dishonest if nobody knows it". Curial e Güelfa...: I, 26-27.

30. "Being very wise at his age, he could become a valiant man if he has what it takes"; "beautiful singer and had learnt to play instruments (matter what made him famous), as well as riding, composing, dancing and jousting". Curial e Güelfa...: I, 30.

31. "Curial played with the ball in front of the palace all the day long, all the time being atched by her". Curial e Güelfa...: I, 47.

32. "she found the little Saintré there, given that she was watching the players of jeux de paume on the courtyard". De la Sale, Antoine. Le Petit Jehan de Saintré...: 16.

33. Curial e Güelfa...: I, 106. 
gives him her heart to eat, we can see Boccaccio's motive mixed with the figure of the popular medieval allegorical figure of the pelican, as presented in numerous bestiaries. The motive of the eaten heart appears in many other texts, as in a tale in the Novellino, very similar to the one that would inspire the ending of Curial and that would provide material for the episode of the nuns, as we shall see below.

We could identify more elements in Curial that come from Petit Jehan de Saintré (for example, the mentions of Bouciquault, Jehan le Maingre, the Duke of Esterich and the lord of Montferrant), but I am interested now in clearly portraying the constructive scheme of the work.

If Curial e Güelfa starts in a evident imitation of Petit Jehan de Saintré, its ending takes after novel LXIV of the anonymous Italian Novellino, o Cento novelle antiche, which in turn imitated the story Atressí con l'orifanz by the troubadour, Ricardo de Barbessieu (Rigaut de Berbezilh), precisely the song in the Catalan novel that Curial composes in Africa to fulfill Güelfa's condition for forgiving him.

Güelfa is furious with Curial because two envious elderly people (playing the role of the lausengier) make her believe that, while in Paris, Curial has bragged about being married to her and having consummated the marriage, the reason for which she was giving him all the money he needed. ${ }^{34}$ The lady swears to forgive the knight only under one condition: if the king and queen of France, all the court and all lovers, gathered in a tournament in Puig de Nostra Dona, ${ }^{35}$ cry out mercè ("grace", "mercy") for him. ${ }^{36}$ Menéndez y Pelayo noted that the Novellino was the source, ${ }^{37}$ though he was based in his master Milà i Fontanals' work De los trovadores en España, as it was Milà who established the relationship between the two works and noted that the story ${ }^{38}$ was a gloss of Berbezilh's song: Atresso com l'orifanz, / que quant chai no.s pot levar / tro li autre, ab lor cridar, / de lor voz lo levon sus. ${ }^{39}$ Milà concludes,

Es de advertir que si bien la biografía de Barbessieu no habla del Puy, cuenta el hecho que motivó la poesía y, en efecto, los versos: 'E si la cortz del Puei e'l ric bobans... No-m relévan, jamais non serai sors' dan más razón a esta parte de la novela que a la biografía.

He also mentions que el gavilán que debía coger el caballero que se proponía costear la fiesta era tenido por el señor del Puy y no puesto en un asta. ${ }^{40}$ The hawk also appears in

34. Curial e Güelfa...: II, 269.

35. The name of this place in France transforms into its equivalent in Curial, Santa María del Puig, an emblematic place in the kingdom of Valencia that is referred to in Ramon Muntaner's Crònica.

36. Curial e Güelfa...: II, 287.

37. Menéndez Pelayo, Marcelino. Orígenes de la novela. Santander: Aldus, 1943: I, 390.

38. Milà i Fontanals, Manuel. De los trovadores en España. Barcelona: Consejo Superior de Investigaciones Científicas, 1966: 105-107.

39. "As the elephant, what cannot raise after falling, till the others, with their shouts, raise it". Riquer, Martí de. Los trovadores. Historia literaria y textos. Barcelona: Planeta, 1975: I, 290.

40. "It is noticed that although the biography of Barbessiu does not speak about the place of Puy, it explains the fact that motived the poem and, indeed, the verses 'E si la cortz del Puei e'l ric bobans... No-m relévan, jamais non serai sors' give more reason to this part of the novel than to the biography"; "the hawk 
the Novellino's tale: In quello giorno, ordinaro la festa, e poneasi uno sparviere di muda, in su un'asta; the person who holds it in the fist is the one who wants to pay for the party. ${ }^{41}$

In the Italian novel (LXIV), the events take place in the same place, Puy de Notre Dame in Provence, and the lady ignores the knight because he has broken the proper secret of courtly love when he bragged about their love. The narrator conceals the name of the knight, — pognamli nomme messer Alamano-, but does give the name of the lady, madonna Grigia. After being dismissed, the desperate knight becomes a hermit. One day, a group of boys from Po arrive at his refuge during a hunting trip and, unaware of his true identity, tell him the story and lament the loss of the best of the knights, but also confess their hope that he will show up at the next tournament. Indeed, the knight appears in the tournament and when they see him, everybody asks him to sing. He agrees to sing only if the lady forgives him. For her part, she will only forgive him if a hundred barons, a hundred knights, a hundred ladies and a hundred maidens demand, shouting together, mercè ("mercy") for the knight and troubadour. In Candlemas, he goes to church and in front of everybody sings his composition Una molto bella canzonetta, none other than Altresi come il leofante / quando cade, non si può levare / e li altri, al lor gridare, / di lor voce il levan suso; / e io voglio seguir quell'uso. Upon listening to him, everybody shouts mercè! and the lady forgives him. ${ }^{42}$

Then, Curial arrives at the tournament in Santa Maria del Puig preceded by six richly dressed pages riding horses, himself with a dark shield and ab un falcó encapellat pintat en mig. Approaching her, he tells the queen, the king and all those present: Yo.us suplich que, demanant mercè, me obtengats perdó, a grans crits, de una senyora que diu que és mal contenta de mi. Eventually, they all plead for everyone in court to shout:

Vírats senyors e senyores en gran nombre e, finalmente, tota la cort, per part del cavaller, cridar a la senyora no coneguda: "Mercè! Mercè! Mercè!". Los crits foren tan grans que no.s oyen uns a altres; e quatre reys d'armes e molts harauts, vestits de la liurea de Curial, anàvan per tota la plaça cridant mercè, e convidant e animant les gents a cridar. ${ }^{43}$

After the general acclaim, Curial shows a black banner, but this time ab lo falcó ja emperò desencapellat ("with the hawk without had"). This hawk is directly related

that the knight willing to pay the party should get, belongs to the lord of Puy and it is not on a bar". Milà i Fontanals, Manuel. De los trovadores en España...: 107.

41. "In this day, during the party, one hawk take place over the bar". Il Novellino (Le ciento novelle antike), intr. Giorgio Manganelli. Milan: Biblioteca Universale Rizzoli, 1999: 4, 73.

42. "Similar to the elephant / that when it falls down, it cannot raise / and the others, throughout their screams / can raise it with the voice / and I wish follow this model". Il Novellino...: 75.

43. "With a hawk with hat painted in the middle"; "I request you that, through your mercy, you can earn mercy for me, with great shouts, from a lady who claims she is upset because of me"; "a large number of lords and ladies and finally, the whole court was yelling to the unknown lady: 'mercy!, mercy!, mercy!'. The shouts were so loud that one disturbed the other one; and four kings of arms and may heralds, dressed according to the line of Curial, were going throughout the square calling for mercy, and inviting and encouraging the people to do the same". Curial e Güelfa...: III, 242. 
to the one in the story, although its function is different. Thus, the love story ends happily.

This is not the only loan from the Novellino. As I anticipated, tale LXII, conta una novella di messer Roberto whose wife, the countess, and her ladies sleep with Baligante, a very tall caretaker. The husband has him killed and del cuore, fe fare una torta, which he presents to the ladies to eat. When everything is known, ashamed of their behavior, they all become nuns in a monastery. However, they establish a new custom:

Quando elli vi passasse alcuno gentiluomo con molti arnesi, ed elle il faceano invitare e facèanli grandissimo onore. E la badessa e le suore li veniano incontro e, in sul donneare, quella che più li piacesse, quella il servia ed accompagnava a tavola ed a letto. ${ }^{44}$

Although the humorous nuns (all of them of noble origin) that Curial and Festa find in a monastery do not go that far, they do display their gusto in welcoming the young knight and indulge in sexual jokes, especially the Abbess Yoland le Mengre, a jove e molt bella senyora, sister of Johan le Mengre, who had recently arrived from the court of the King of France: Totes les monges feyen tanta festa a Curial e a Festa, e ab tanta alegria reyen, que açò era una gran meravella..$^{45}$ Festa tells the nuns, Yo us veig de tal pèl, que encara esta nit jugaríets a punyades qual de vosaltres l'auria. ${ }^{46}$ Another illustrious nun, Johanina of Bourbon, jokingly asks Festa to exchange roles and gowns, so that she can accompany the knight as a maidservant. The ending of their stay in the monastery offers an unbelievably astonishing situation: fet en terra un llit molt gran, totes vestides jagueren ensems, en manera que no s'i dormi, ans tota la nit en trufes e plaers totalmente traspassaren. ${ }^{47}$ All the nuns and Festa in a single bed, having fun all night en trufas e plaers! When Curial and Festa meet the nuns again, we find a loan from Quijote: Curial viu gran pols de gents qui venien per lo camí. He himself tells it to the knight he is about to fight: Cavaller, yo veig gran pols e pens que sien gents qui vénen vers nosaltres, but it is only the abbess and a group of nuns! ${ }^{48}$ In Quijote, ${ }^{49}$ according to the knight, the clouds of dust did not hide nuns but armies, which in reality turned out

\footnotetext{
44. "he told a story about master Roberto"; "it was done a cake with the heard"; "When some wellregarded man crossed there worn with good hamess, the women ordered to invite them and they gave them a great honours; and the abbess and the sisters went to find him, and this one that liked him the most, this one served to him at the table and in bed". Il Novellino...: 70.

45. "A young and very beautiful madam"; "all the nuns held such a big party for Curial and Festa, and they laughed with so much joy, that this was all a great delight". Curial e Güelfa...: II, 43.

46. "I see you look so good, that I'm sure that this night you will play to decide which of you will get him". Curial e Güelfa...: II, 44.

47. "A big bed made on the ground, all of them lay dressed together, and they did not sleep anymore, but spent all the night in entertainments and pleasures". Curial e Güelfa...: II, 47-48.

48. "Curial saw a big dust cloud from people coming by the path"; "Knight, I see a big dust cloud and I wonder if this is people coming to us". Curial e Güelfa...: II, 57-58.

49. Cervantes, Miguel de. El ingenioso Hidalgo Don Quijote de la Mancha. Madrid: Espasa-Calpe, 1976: 92-99 (first part, chapter XVIII).
} 
to be a flock of rams and sheep. If Curial surpasses the irony of Quijote it is because its author knew Cervantes' book very well.

The love story between Curial and Güelfa begins as the story of the dame des Belles-Cousines and Petit Jehan de Saintré, but ends as the story of madonna Grigia and the courteous troubadour called messer Alamano, with forgiveness bestowed on him thanks to the clamor for: Mercè! And in the middle, acting as a poetic link between the two stories, Rigaut de Belbezilh's song, which the Catalan novel credits as being composed by Curial in Africa.

Among the many other ingredients the writer mixes in his composite fable, we also find two episodes from Paris e Viana that we now summarise.

\section{Two episodes from Paris e Viana in Curial e Güelfa, and embroidery from Luis Milán's El Cortesano}

In the times of the great emperor, Charles, king of France, son of King Pippin, the Dauphin of Viana was a noble named Godofre de Lançó, who belonged to the Emperor's lineage and was married to the daughter of the count of Flanders, with whom he had a beautiful daughter called Viana. A handsome young knight called Paris, molt gran sonador e cantador ("very great musician and singer") and skilled in hunting and arms, falls in love with her; but being the son of micer Jacobo, a nobleman who lived in the lands of the Dauphin, he lacked the status of Viana. The young man thus began his courtly siege of the lady incognito, first by means of singing and music, and later by military exercise. He seduces her and wins many victories, but still does not reveal his identity.

Viana ignores the name of this young man who admires her so. After winning a tournament in Paris, Paris accompanies his friend Eduardo to Bravante to see his lady, and leaves the keys of his chamber with his mother, warning her against letting anyone in. But when his father falls ill, and the Dauphine, and later his wife and daughter Viana, visit him, Paris' mother shows the castle to the ladies, including his son's room. In it, Viana discovers una cuberta de cavall tota blanca, which she recognizes as belonging to Paris. Flustered and nearly fainting, she asks Paris' mother if she can rest for a while. Left alone with her maid and friend Isabel, the two enter Paris' chamber:

Elles entraren en un studi no gran, hon estaue la ymatge de Nostre Senyor ab lanties e
canalobres d'argent. E aqui Paris se retraya per ses deuocions, e aqui era la bandera blanca
e totes les joyes que ell hauia guanyades en la ciutat de Paris. Vaent Viana aquestes coses, fou
certa que Paris era aquell qui tant hauia desitjat saber. ${ }^{50}$

50. "A horse's cover, absolutely white"; “They entered a not very large study, where there was the image of Our Lord with silver lamps and candelabras. Here, Paris harboured in his devotions, and here it was the white flang and the whole jewels he won in the city of Paris. Viana, seeing all these items, believed 
Viana takes some jewels to have an excuse to come back and talk to him to confirm what she already knows: that he is the unknown knight. Viana's entrance in the chamber is thus purposeful: the recognition of Paris as the knight who has served her so well.

There are two similar scenes in Curial. The first takes place at the Duke of Bavaria's castle. After dinner, the duke refuses Curial's departure, ans en la cambra on Laquesis dormir solia, molt ricamente aparellada, ordonà que dormís. ${ }^{11}$ The duchess invites him to sleep in the bed of her daughter Laquesis: Curial, vets ací lo llit de Laquesis; dormits bé e guardats-vos que no somiets algun mal. In the chamber there is an altar: Havia en aquesta cambra un altar a una part, ab un retaule de mossenyor sant March, molt finamente acabat; he remembers Güelfa, and guiltily, kneels and cries in front of the altar. But his sorrow is short-lived: Llevant-se del altar, se'anà al llit, lo qual era molt ricamente cubert d'un cubertor tot blanch, de domàs forrat de herminis, brodat d'ulls e de llaços d'or, segons era la roba de Laquesis. D'aquest mateix domàs eren les cortines, en aquesta matexa forma brodats. ${ }^{52}$ Then he sees a boudoir en la qual havia un altre llit molt bell e ricós, sobre.l qual trobà totes les joyes de Laquesis; he inspects the jewels one by one during almost all night, amazed at so much wealth. ${ }^{53}$

The second scene occurs shortly after in Montferrat, the monastery of the abbess. There, the Catalan knights who fight alongside Curial use Güelfa's chamber. Curial and Melchior are the first to arrive, and the nuns welcome them with a procession $e$ anaren ab ells a la esgleya cantant ymnes devots, e aprés anarense'n a la cambra on la Güelfa solia estar. Curial sleeps in Güelfa's bed, but before he goes to l'altar de mossenyor sant March on la Güelfa s'agenyollava per dir oració, agenollà's tantost e, feta oració, se'n vench al llit de la Güelfa, e mirant-lo sospirá. ${ }^{54}$ The abbess tells Güelfa the next day: En vostre llit ha dormit esta nit. ${ }^{55}$

In Paris e Viana, their use as anagnorisis justifies the bed and the gaze upon the jewels; conversely, in the imitation of the scene that appears in Curial e Güelfa, there is a modern ironic tone, the same that pervades and defines the novel.

The two stories share another important element. Returning from seven years of imprisonment in Africa, Curial goes to Monferrat. There, instead of announcing

that it was Paris who she so wished to know". Paris e Viana. Histories d'altre temps, ed. Ramon Miquel y Planas. Barcelona: Nova Biblioteca Catalana, 1910: 96.

51. "instead, he ordered that he sleept in the room where Laquesis used to sleep, very well prepared". Curial e Güelfa...: I, 101 .

52. "Curial, see here the bed of Laquesis, sleep well and try not to have any nightmares"; "somewhere on one side of this room there was an altar and an alterpiece of Saint March, very finely finished"; "rising from the alter, he went to bed, what was richly coverted by an all white cover, made of damask with ermine, embroided with gold bonds, as were Laquesis' clothes. The curtains were the same damask, and with the same embroideries". Curial e Güelfa...: I, 103.

53. "there were another bed very beautiful and rich, where he found the all Laquesis' jewels". Curial e Güelfa...: I, 104.

54. "and they went with them to the church, singing hyms and after they went to the room where Güelfa used to be"; "the altar of mylord Saint March where Güelfa kneeled to pray, he kneeled at it and, after praying, he went to Güelfa's bed, and looking at it, sighed". Curial e Güelfa...: I, 173.

55. "He has slept this night in your bed". Curial e Güelfa...: I, 175. 
himself to Güelfa, he joins a group of beggars asking for leftovers at the palace gates. With his loyal Galcerán de Mediona, Curial sings his song. The fame of the singing beggars reaches the marquis and he refers it to his sister Güelfa, who wants to hear them. She does not recognise a poor, bearded Curial, who calls himself Johan, says he is from Normandy, and, even more, speaks French! The lady asks him to recite the song, que li digués de paraula (Milà, as a great specialist in folk culture, knows very well that one may know how to sing a song but not to recite its lyrics) and he obliges. ${ }^{56}$ After listening to him, Güelfa inquires about its author and Curial says that he learnt it in Tunisia. When the lady confesses that she knows who composed it, Curial finds a way to identify himself and speaks in the Lombard language, the only way she can recognise him.

In Paris e Viana, Paris and his friend Adoardo sings under the window of the beautiful Viana, sonauen e cantauen marauellosament. ${ }^{57}$ They manage to flee from the ten men sent by the Dauphin to catch them. If we connect this episode to Paris' return from Alexandria, it is evident that the story is one of the sources for Curial. The young man has freed his beloved father and in return, he asks to marry her, though he remains incognito. A monk who only speaks morisch accompanies him; nobody recognises him, not even his friend Adoardo. In front of Viana, he shuts up and only the monk speaks; he only reveals his true identity by means of the ring she had given to him, and only after she sees the ring does he start to speak and confess his identity: E Viana, que estaua marauellada del diamant, fon mes marauellada com hoy parlar aquell qui james hauia parlat, en tant, que estech spantada..$^{58}$

As an example of Milà's work of marquetry with his different sources, let me note the embroidery on the white damasked quilt that covers the bed where Curial sleeps: brodat d'ulls e de llaços d'or, segons era la roba de Laquesis. D'aquest mateix domàs eren les cortines, en aquesta matexa forma brodats, ${ }^{59}$ previously described like this: una roba de domàs blanch forrada de herminis, tota brodada d'ulls, dels quals exien laços d'or fets en diverses maneres. ${ }^{60}$

An infatuated Laquesis gifts him a gown and asks him to make shirts with it - jupons - which Curial would wear all the time. When Güelfa learns this, she becomes very jealous and demands that Curial hand the shirts and Laquesis' bed cover (we did not know that he had it) to her. Then, Güelfa, secretament, mès mans a fer una tenda d'aquells paraments de cortines gives them as a present to Boca de Far, ${ }^{61}$ Curial's opponent, who courts her. No other novel makes more of a cloth! It is fair to acknowledge that the idea of the embroidered eyes and buttonholes is Valencian

\footnotetext{
56. "to say it in words". Curial e Güelfa...: III, 167.

57. "they played and sang fantastically". Paris e Viana...: 84.

58. "And Viana, who was astonished because of the diamond, became more astonished when she heard him speak what has never before been spoken, and she got scared". Paris e Viana...: 125-126.

59. "embroided with gold bonds, like Laquesis' dress. The curtains were the same damask, and with the same embroideries". Curial e Güelfa...: I, 103.

60. "a dress of damask with ermine, absolutely embroided with eyes, which had gold bonds, made in different forms". Curial e Güelfa...: I, 99.

61. "secretely, she made an effort to do a tent with these items of the courtain". Curial e Güelfa...: I, 159.
} 
and not German; in Luis Milán's El cortesano, a knight representing Desire appears very well dressed, with a terciopelo carmesí, con unos ojos en blanco mirando al cielo, broslados entre muchas alas de oro de martillo, esmaltadas, y en un sombrerete de lo mismo traía este mote que decía: 'El deseo siempre vela, mira y vuela'. ${ }^{62}$ There was a golden wing in the Duke of Orleans' banner, for a reason known to all: Lo duch d'Orleans vench avant ab un standart vert e una ala d'or, e tothom pronusticà que, per ço com Laquesis era alamanya, feya aquella ala. ${ }^{63}$

We find a damasked bed cover like the one in El Cortesano by Luis Milán covering the bed in Paris e Viana and in Curial e Güelfa: the quilt in such an interesting 'Gothic' work as Curial e Güelfa is made with ideas from many different texts that make up an erudite marquetry.

\section{Troubadours and other characters that appear in the novel}

Apart from Rigaut de Belbezilh and his song, there is another troubadour who makes it into the story: Raimbaut de Vaqueiras (1180-1205). We find evidence of this in his 'Life':

Raembautz de Vaqueiras si fo fillz d'un paubre cavaillier de Proensa, del castel de Vaqueiras, que avia nom Peirors, qu'era tengutz per mat. En Raembautz si se fetz joglar et estet longua saison ab lo prince d'Aurenga, Guillem del Baus [...]. E venc s'en Monferrat, a miser lo marques Bonifaci. Et estet en sa cort lonc temps. E crec si de sen e d'armas e de trobar. Et enamoret se de la serror del marques, que avia nom ma dompna Beatritz. ${ }^{64}$

Son of a poor knight from Provence, this troubadour fell in love with the sister of the marquis of Montferrat, Beatriz (according to Riquer, she was not the sister but a daughter of the marquis, but Milà did not know this detail ). ${ }^{65}$ It concords

62. "crimson velvet, with white eyes looking at the sky, placed between wings done in hammered gold, enameled and crowned by a hat showing a motto that stated: 'the desire always looks for, watches and flies'". Milán, Luis. El cortesano, ed. Marqués de la Fuensanta del Valle; José Sancho Rayón. Madrid: Colección de libros españoles raros o curiosos, 1874: 378.

63. "The Duke of Orleans went ahead with a green standard and a gold wing, and everybody wondered what, given that Lasquesis was German, she was doing there". Curial e Güelfa...: II, 130.

64. "Raimbaut de Vaqueiras was the son of a poor knight of Provence from the castle of Vaqueiras, whose name was Peiror, who was seen as a fool. Raimbaut became a jongleur and lived a long time with the Prince of Aurenga, Guilhem dels Baus [...]. And he went to Monferrato, to see my lord the Marquis. And he spent a long time in his court. And he improved in sense, arms and composing. And he fell in love with the sister of the Marquis, who was my madam Beatriz". Los trovadores...: II, 815.

65. Canto IV of Comedia de la gloria d'amor by Fra Rocabertí (Bernat Hug de Rocabertí. "Comedia de la gloria d'amor", Essai sur la literature catalane, ed. François Roman Cambouliu. Paris: Durand, 1858: 110176) refers to Gismunda and Guiscard - the characters of the first novel of the fourth day of Decameron, mentioned by Laquesis in Curial (Curial e Güelfa.... II, 201, 205) - and right after: Alsant los ulls io viu quasi torrat / estar d'amor N'Rambau de Vaqueres / e Beatrix nobla de Montferrat ("Raing the eyes, I saw almost toasted, / being in love Ramau de Vaqueres / and Beatrix, noble woman of Montferrat"). Milà notes the 
with the story of Curial but for a small detail, which can be explained by the strong admiration of the great Catalan erudite for the Guelph author Dante: Beatriz is Beatrice Portinari, the lady celebrated by Dante; that is, she is a Guelph (Güelfa). Could this explain why the female character of the novel does not have a proper name?

The razó that accompanies the most famous Provençal estampie, Kalenda Maia in Vaqueiras, is even more significant:

Ben avetz auzit de Rambaut qi el fo ni don, et si com el fo fait cavalier del marqes de Monferrat, et com el s'entendeia en ma dompna Biatrix et vivía jausen per lo so amor. Et aujatz com el ac um pauc de temps gran tristessa. Et aiso fon per la falsa jen envejosa a cui nom plasia amrs ni dopneis, qe dizion paraolas a ma dompna Biatrix et encontra las autras dompnas, dicen aisi: 'Qi es aqest Rambautz de Vaqera, sitot lo marqes l'a fait cavalier? Et si va entendre en tan auta dompna con voz o ez! Sapchatz qe no.n vos es onor, ni a vos ni al marqes'. Et tan disseron mal, qe d'una part qe d'autra (si con fan las avols genz), que madompna Biatrix s'en corecet contra Rambaut de Vaqera. ${ }^{66}$

Another detail of this loan from the troubadours is that, at the end of the novel, the king of France bestows lo principat d'Oreng on Curial, ${ }^{67}$ and Vaqueiras is, according to Martí de Riquer, localidad provenzal cuyo castillo pertenecía al linaje de los Baus, a la sazón príncipes de Aurenga (Orange), en cuya corte, según afirma la Vida pero no confirman otras fuentes, Raimbaut ejerció la juglaría e inició su obra como poeta. ${ }^{68}$ Thus Curial, after copying his life in fiction, ends up being from the prince of Raimbaut's birthplace (and, we can assume, also lord of 'Milà').

In De los trovadores en España, Milà i Fontanals says that Rambaldo de Vaqueiras (1180-1207) fue trovador y compañero de armas de Bonifacio, marqués de Montferrat, a quien siguió en expediciones oscuras y gloriosas, ${ }^{69}$ however, a little later, he mistakes the

work of comendador Rocabertí: donde se introducen, 'como en el trionfo d'amore', varios personajes víctimas de su pasión ("where different personages victims of their passir were introducted, as in the trionfo d'amore"), and cites this stanza in: De los trovadores en España...: 455.

66. "You have well heart who was Raimbaut and from where and how he was created Knight by the Marquis of Monferrato, and how he was fallen in love with my lady Beatriz and he lived content because of her love. And hear how he became immensemly sad during a few time. And this was because dishonest people who did not like love and gallantry said to my lady Beatriz, staying among madames, words like the following: 'Who is this Raimbaut de Vaqueiras, although the Marquis had made him Knight? And he dared to fall in love with such a high Lady as you! You must know that this is not honourable for you nor for the Marquis'. And so bad words said in one and another place (as usual in the perverse people), that my Madam Beatriz became annoyed with Raimbaut de Vaqueiras". Riquer, Martí de. Los trovadores...: II, 834-835.

67. "the Principality of Orange". Curial e Güelfa...: III, 249.

68. "town in Provence, whose castle belonged to the Baus lineage, then princes of Aurenga (Orange), in whose court Raimbaut played as jongleur and started as a poet, according to the 'Life', although it is not stated by any other source". Riquer, Martí de. Los trovadores...: II, 811.

69. "Raimbaldo de Vaquerias (1 180-1207) was jongleur and brother in arms of Guillermo IV of Baucio, count of Orange; he shows up linked to his lord by the same devoted and enthousiastic friendship that after he gave to his brother in arms Conrado de Montferrat". Milà i Fontanals, Manuel. De los trovadores en España...: 47. 
name of the marquis for his brother's: Este poeta, amigo y servidor de Guillermo IV de Baucio, conde de Orange, se muestra unido a su señor con aquella amistad fiel y entusiasta de que dio más tarde nuevas muestras de su hermandad de armas con Conrado de Montferra. ${ }^{70}$

This blunder by a great scholar, mistaking Bonifacio with his brother Conrado, ${ }^{71}$ links his literary adventures in the Holy Land with Walter Scott, one of the authors Milà admired most. ${ }^{72}$

In Poetas catalanes del siglo XIV (published in 1862), Milà i Fontanals discusses Pere de Queralt, who was armado caballero en 1399 en la coronación de don Martín, quien en el mismo año y en 1401 confiole importantes comisiones cerca del rey de Túnez. He continues:

Cuéntase que esta amistad nació de la siguiente manera: habiendo sido hecho Pere prisionero de los moros, quisieron estos convencerse de si su arrojo respondía realmente al sobrenombre que todos le daban, cor de roure, y así obligáronle a luchar con un león, al cual dio muerte el caballero catalán con un puñal. Esta hazaña, que le valió la libertad, hallábase representada en tres distintos lugares del monasterio de la Merced de Santa Coloma de Queralt y dio ocasión a que la ilustre familia del héroe adoptase por nuevas armas un león rampante en campo rojo, atravesado el pecho con un puñal. ${ }^{73}$

This fragment already presents part of Curial's adventures in Africa. To find others, we can read Milà's De los trovadores en España, where he refers to the brother of King Alfonso $\mathrm{X}$ the Wise, que se dio a conocer en Europa por su vida inquieta y aventurera:

El infante D. Enrique, hermano del rey, vencido en 1259 por D. Nuño de Lara, alcaide de Jerez, que envió el rey contra el infante rebelde, se refugió en Túnez, donde permaneció algunos años sirviendo al rey moro, hecho mencionado en unos de los serventesios de Ramon de Lator de Marsella.

70. Milà i Fontanals, Manuel. De los trovadores en España...: 85.

71. Milà himself noted that the main character of the fifth novel of the first day in the Decameron is Conrado's first wife: El marqués de Monferrato, hombre de gran valia, gonfalonero de la Iglesia, habia pasado a ultramar en una gran expedición armada hecha por los cristianos ("The Marquis of Monferrato, a man of great worth, gonfaloniere of the Church, had gone overseas on a large armed expedition made by Christians"); she became a widow after his participation in that crusade (historical data serves although it is not exact). Boccaccio, Giovanni. Decamerón, ed. María Hernández. Madrid: Cátedra, 1994: 180.

72. Coll-Vinent, Sílvia. “Walter Scott en Milà i Fontanals, o la influència del 'Romanticisme saludable' (1839-1854)", El llegat Milà i Fontanals a la biblioteca pública episcopal de Barcelona, Sílvia Coll-Vinent, Isabel de Colmenares, eds. Barcelona: Universitat Ramon Llull, 2011: 89-116.

73. "Became a knight in 1399, during the coronation of don Martin, who in the same year and in 1401 gave him important missions before the king of Tunisia"; "It is said that this friendship was born as following: after Pere being taken prisoner by the Moors, they wished to find out whether his bravey was coherent with his nickname he was known by everybody: heart of oak; and so he was forced to fight a lion, which was killed by the Catalan knight with a knife. This great feat is explained in three different places of the Monastery of the Mercy in Santa Coloma de Queralt, and it earned freedom for the Knight and allowed the distinguished family of the hero to use a shield showing a rampant lion with a knife in its heart on a red field". Milà i Fontanals, Manuel. Estudios sobre Historia, Lengua y Literatura de Cataluña. Obras completas, ed. Marcelino Menéndez Pelayo. Barcelona: Librería de Álvaro Verdaguer, 1890: III, 330. 
He later served Charles of Anjou and took part in the battle of Benevento (1265), in which Charles obtained Naples and Sicily. $Y$ al año siguiente se unió con su hermano Fadrique, que seguía el partido de Conradino. ${ }^{74}$

It is not strange that don Enrique de Castilla defended Curial when the later was in the lions' pit: ...un cavaller d'Espanya, qui don Henrich de Castella havia nom e tenia mil rocins de christians e gatges del rey, suplicà al rey que fes aquella gràcia a.N Ramon Folch, ${ }^{75}$ the said grace being the freedom of Curial.

We should not be surprised either by the fact that the opponent of Aznar de Atrosillo was the knight, Guillalmes de la Tor, the same name as the trobadour Guilhem de la Tor (circa 1216-circa 1233), who, though born in Périgord, moved to Lombardy. In Milan, he fell in love with the young wife of a barber, whom he kidnapped and took to Como. Legend (or his Life) has it that grief took him after she passed away. Among the characters in his Treva we find Selvaggia and Beatrice, the two daughters of Corrado Malaspina. ${ }^{76}$

In addition to the trobadours, in Curial we also find traces of episodes from two Catalan chronicles seasoned with details from the Gothic novels of Walter Scott.

\section{The presence of Ramon Muntaner and Bernat Desclot's Chronicles in Curial}

The author of Curial had read both chronicles and found inspiration for some episodes in his novel from them. While Lola Badia and Jaume Torró have noted that there are afinitats manifestes del Curial amb les cròniques de Desclot $i$ de Muntaner, ${ }^{77}$ they did not examine how the alleged anonymous author could access these and other sources. In Desclot's Crònica, we read, Com lo comte de Barcelona anà en Alemanya, ab sol un cavaller, per excusar l'emperadriu d'Alemanya, an evident model for the battle of Curial and Jacob of Cleves in defence of the Empress and her first cousin Cloto, daughter of the Duke of Bavaria and Duchess of Ostalriche, who had been falsely accused of adultery. The knight Bertran de Rocabruna accompanies the

\footnotetext{
74. "he became famous in Europe thanks to his fidgety and adventurer life"; "Prince henry, brother of the king, defeated in 1259 by the alcaide of Xerez, Don Nuño de Lara, was the king sent against the rebel prince, took refuge in Tunisia, where he lived some years serving the Moorish king, which was mentioned in some poems written by Ramon de Lator of Marseille"; "And in the following year he joined his brother Fadrique, who supported the party of Conradino". Milà i Fontanals, Manuel. De los trovadores en España...: 192-193.

75. "a knight from Spain, named Henry of Castile, who had one thousand horses of Christians and the guarantee of the king, demanded to king that he gave this grace to Ramon Folch". Curial e Güelfa...: III, 157.

76. Riquer, Martí de. Los trovadores...: II, 1171-1172. Auger Bellian, the old knight defended by Curial, has two coward sons: Perrin and Hans (Curial e Güelfa...: I, 57). Perrin is the name of the minstrel sent by Guiraldo de Borneil to the king of Aragon. Milà i Fontanals, Manuel. De los trovadores en España...: 128.

77. "manifest affinities between Curial and the chronicles of Desclot and Muntaner". Badia, Lola; Torró, Jaume. "Introducció...": 62-65.
} 
Count of Barcelona. Both ladies, in the gallows, with firewood at their feet, await God's judgement, which would be expressed in the victory of either the defending knight or the two accusing lausenger. The count of Barcelona wins, killing one of the two German knights, while the other confesses the falsity of their accusation in front of the whole court: Jo dic davant tota la cort que ço que nós havem dit de madona l'emperadriu, dixem per enveja e per mala volentat. The count takes the knight to the Empress: Ab tant menà-lo hom denant l'emperadriu, qui estava en una casa de fust que hom li havia feita denant lo camp, e aqui de prop havia bastit un gran foc, que si el comte fos vençut, que fóra cremada, ${ }^{78}$ and she forgives him.

In Curial, Curial and Jacob of Cleves fight against Parrot de Sant Laydier and Othó de Cribaut, respectively, in a similar battle. Othó confesses that the duchess was innocent. But Jacob, who had made the accusation, $m^{\prime}$ avia tret de ma honor, lançantme de la privadesa del duch; vengeance the reason for such terrible accusation. In this case, the scene does not end with the forgiveness of the falsely accusing knights, but with their punishment: La duquesa fonch devallada del cadafal, e muntarent-hi los dos falsos cavallers, e encès lo foch, moriren a cruel e vergonyosa mort. ${ }^{79}$

Desclot also refers to the trip by Peter III to France in disguise, which is the base of the knight of the black shield in the tournament in Melun that appears in Curial, an episode that also appears in Ramon Muntaner's Crònica, to which we now turn.

The confrontation between Charles of Anjou and King Peter III for Naples and Sicily ends with the challenge of Bordeaux. As the king of England cannot guarantee the safety of the king of Aragon, he advises against going to the battle in the French city. But King Peter, who is determined to go to battle, travels under the identity of the merchant Domingo de la Figuera.

Així que nostra volentat és que aital jorn que deu ésser lo jorn qui és emprès, que siam al camp de la batalla, en Bordeu; e que nós que hi anem en persona en aital manera: que vós irets cavalcant en un bell cavall, con a senyor, e nós irem així con a escuder vostre, en un altre cavall, ab una ascona muntera en la man; e haurem En Bernat de Peratallada, qui cavalcarà en altre cavall ab una sella de trossa, e portar-vos ha la trossa, qui serà lleugera, que no hi haurà mas la vostra gramalla e diners per despesa, e portarà altra ascona muntera. ${ }^{80}$

78. "How the Count of Barcelona went to Germany, accompanied by only one knight, to defend the Empress of Germany"; "I state in front of the whole court that this said by us regarding her Highness the Empress was said for envy and evil intention"; "In the meantime, he was shown in front of the Empress, who was in a wooden house built for her in front of the field, and in this place a big fire was made, and it was said that if the count was defeated, she would be burned". Desclot, Bernat. Crònica, ed. Miquel Coll i Alentorn. Barcelona: Edicions 62, 1982: 68.

79. "he betrayed my honour, the reason why I lost the friendship of the duke"; "the duchess was taken out of the catafalque, and the false knights took their place and they were burned on the pyre, so they died awfully and cruelly". Curial e Güelfa...: I, 83.

80. "Our will is that in the convened day we must be on the battle field, in Bordeaux, and that I must arrive on personally in the following way: you will go riding a good horse, as a lord, and I will go as your squire on another horse, with a short lance in my hand; we will meet Bernat de Perratallada, who will ride another horse, with a light saddlebag to carry just the good dress and money for the travel, and also he will carry another short lance". Muntaner, Ramon. Crònica, ed. Marina Gustà, Barcelona: Edicions 62, 1979: I, 138. 
This they did, and when the king arrived at the battlefield, he sent his emissary, Gilabert de Cruilles, to look for the seneschal and tell him that a knight of the king of Aragon wanted to talk to him and requesting him to come with a notary and six knights. These would act as witnesses (and a scribe will write it all down) to the presence of the king of Aragon on the battlefield on the set day. The king only revealed his identity at the precise moment, after which he returned to Aragon immediately, in the same way, but this time taking a route through Castile. ${ }^{81}$

This trip of the king of Aragon is behind the episode of the same Peter III in France for the tournament in Melun that appears in Curial. The narrator follows the arrival of the king, who conceals his identity as an errant knight:

En aquest mateix temps, lo rey d'Aragó, que tres mesos o més havia cavalcat contínuament, a forma de cavaller errant e, sens ésser estar conegut, havia fetes coses de son cors dignes de recordable veneració (e, sinó que no-s pertany a nostra matèria tractar sinó dels fets de Curial, yo scriuria ací alguns notables actes qui són venguts a noticia mia, los quals per les sues valeroses mans foren finats a honor sua, no menors ne de menor perill que aquells que de sus havets legits), tramès les sues tendes al camp (no riques, per ço que les endes no.l descobrissen), e manà que fossen fermades en lo pus desviable loch que s'i trobàs; e axí fonch fet. $^{82}$

The knights from Aragon, who are accompanying Curial, recognise his king, ask him to admit Curial to his company, and the king obliges; travelling together, they will be known as the knights of the black shield. There is even a mention of Charles of Anjou:

E lo rey, qui havia un poch lo ventrell gros contralls franceses, per rahó del duch d'Anjou, qui havia mort son sogre, mirà vers aquella part on los angleses rompien lances contra.ls franceses, e axí, lo rey ficà sperons al seu cavall, apellat Pompeu, e sí anà vers lo duch d'Orleans. ${ }^{83}$

His actuation in the tournament next to young Curial has yet another source: Walter Scott's Ivanhoe. The main characters of this Gothic novel are two errant knights who conceal their identities: although Ivanhoe reveals it soon, the Black

81. Muntaner, Ramon. Crònica...: I, 141-142, 146.

82. "At that same time, the King of Aragon, after riding continuously for three months or more, like an errant knight and, without being recognised, had done deeds with his body worthy of recordable veneration (which I don't explain because our matter consists in dealing with the events in Curial, although I would write here some notable acts that have come to my notice, which are honourablely done by his hands and they are not menor nor less dangerous than those acts you have read above). He sent the tents to the field (which were not rich in order not be uncovered) and he ordered that they were stablished in a discret place, as it was done". Curial e Güelfa...: II, 110-111.

83. "And the king, who was annoyed with the French, because of the Duke of Anjou, who had killed his father-in law, looked to that place where the English were standing up against the French, and so, the king spurred on his horse, called Pompeu, and he rode towards the Duke of Orleans". Curial e Güelfa...: II, 114. 
Knight will only abandon his anonymity at the end of the story: he is Richard the Lionheart.

When the young knight appears at the tournament organised by prince John, people only see a rather thin knight of medium height, riding a dashing black horse, his suit of armour was formed of steel, richly inlaid with gold, and the device on his shield was a young oaktree pulled up the roots, with the Spanish word Desdichado, signifying Disinherited. ${ }^{84}$

During a melee, the knight is hard pressed by Brian de Bois-Guilbert, Athelstane and Front-de Boeuf. At this point, a warrior from his entourage, clad in black armour and riding a robust black horse, without any ensign on his shield, comes to his help, knocking over two of the opponents and evening up the fight for the hero, who wins the tournament in Ashby-de-la-Zouche and reveals his identity when he removes his helmet, fainting. The Black Knight appears in the tale and his identity gradually becomes known, first only by some characters and eventually by everybody.

In Curial, all the knights that accompany the king of Aragon at the tournament in Melun have the same black shield with an ensign on it, although the comedy that characterises Curial can be perceived in the fact that the narrator says that per ventura mal pintada, per ço que a la brevitat del temps no consentia que millor se fes. ${ }^{85}$ The black shield becomes so much connected to this group of knights that the Duke of Orleans, ${ }^{86}$ playing a little trick (something really astonishing among errant knights!), takes a black shield to Laquesis for her to touch so that he can later affirm: Yo dich que la donzella que té l'escut negre és la pus bella del món ${ }^{87}$ being faithful to Laquesis while everybody thinks he is praising Festa, the lady who accompanies Curial and who the knights from Aragon defend.

The knight of the black shield hurt the king of France, who has decided boldly to join the joust. After being defeated, the king is content with having broken a spear on the shield of the world's best knight. The king of Aragon is thus the bravest knight, even though Curial, who at this point is furious, encès per rahó de un anglès qui falsamente, ab una lança, l'avia ferit, takes part in the tournament. ${ }^{88}$

Shortly after, the king of Aragon has to intervene like the Black Knight: attacking to defend Curial who, like Ivanhoe, is being attacked by various opponents at the same time.

At the end of book I in Curial, the narrator presents King Peter, cavaller molt rebust, forts e valent, lo qual mentre visqué féu de son cors en batalles moltes coses dignes de recordable

84. Scott, Walter. Ivanhoe. London: Penguin Books, 1984: 96 (first edition in 1819). Ivanhoe would thus be called the Disinherited Knight, although the Spanish word desdichado means "unfortunate".

85. "accidentaly, bad painted, so that the brevity of time did not allow it to be done better". Curial e Güelfa...: II, 125 .

86. The Duke of Orleans is also a starring character in Quentin Durward, in which he fights the main character for the lady's love, as in Curial.

87. "I say that the girl who has the black shield is the most beautiful in the world". Curial e Güelfa...: II, 134.

88. "furious about an Englishman who had falsely injured him with a lance". Curial e Güelfa...: II, 139. 
veneració, axí contra sarrayns com altres gents. ${ }^{89} \mathrm{He}$ is a generous host to his subjects, the three knights from Aragon, Dalmau d'Oluge, Roger d'Oluge and Ponç d'Orcau, who had triumphed over Gerardo de Perugia, Frederico de Venosa and Salones de Verona, while Curial finished off Boca de Far. ${ }^{90}$

Surprisingly, the king orders two of his sons to hold torches to lighten the chamber while another serves them food; they would have some rest from their 'work' only in the king's absence:

Los altres dos fills, don Jayme e don Frederich, stigueren als caps de la taula amb sengles torxes en les mans tant com lo sopar durà; e com se enujaven acomanaven-les algun poch a cavallers notables qui de prop los staven, emperò com viandes venien o lo res venia, ells prenien les torxes. ${ }^{91}$

The scene makes sense when compared with a wager that appears in another work by Walter Scott, A Legend of Montrose. Angus MacAulay sits at Sir Miles Musgrave's table, richly lit by six huge silver chandeliers. The Scottish lord is told that such riches are impossible to find in his miserable land, and in turn, he retorts that within his castle they would find more and more precious chandeliers. As he is penniless, his English guests find the following scene:

The large oaken table was spread with substantial joints of meat, and seats were placed in order for the guests. Behind every seat stood a gigantic Highlander, completely dressed and armed after the fashion of his country, holding in his right hand his drawn sword, with the point turned downwards, and in the left a blazing torch made of the bog-pine. ${ }^{92}$

The English lords have to accept that these chandeliers are more valuable than Sir Musgrave's silver ones. In the hands of Milà, this anecdote becomes a lighter and funnier scene, as the mischievous youngsters do not hesitate to take a break from such a strange task.

Returning to Ramon Muntaner's Crònica, let me point out some other details that are recreated in Curial. Muntaner underscores that James of Aragon invites

89. “[a] very robust, strong and brave knight, who while he lived in his heart many memorable battles worthy of veneration, both against the Saracens and other people". Curial e Güelfa...: I, 185.

90. Undoubtedly, the name 'salones de Verona' is humorous and shows the 'modern' irony of the narrator, comparable with the name Bonifaci de Verona, cited by Muntaner in his Crònica (Muntaner, Ramon. Crònica...: II, 123, 126); in contrast, Boca de Far —so close to Tirant's Simon de Far- is very present in Muntaner's Crònica as a geographical reference: "at dawn they were in Boca de Far, before the tower of the lighthouse of Messina". Muntaner, Ramon. Crònica...: I, 103.

91. "The other two sons, Prince James and Prince Frederick, were at the heads of the table with torches in their hands while the supper lasted; and when they became anoyed, they gave the torches a while to a some notable knight what was closed, but they brought them when the food or the meat came". Curial e Güelfa...: I, 186.

92. Scott, Walter. A Legend of Montrose. ed. Jim Manis. Pennsylvania: Pennsylvania State University, 2002: 51 (first edition was published in 1819). 
the king of Castile to Valencia and does not let him spend anything: que anc un diner no despeneren, ell ni persona qui ab ell hi fos. ${ }^{93}$ Later, when the king of Castile crosses Aragon to attend the council in Lyon, the same occurs:

\begin{abstract}
E lo dit señor rei En Jacme d'Aragó e los infants hagueren gran plaer e pensaren d'ordonar per lla on començarien a entrar per llur terra entrò a Montpestller les viandes e tot ço que ops haurien. Que en tal manera dreçaren que jamés negun señor no fos tan bastat ab totes ses companyes com ell fos; e de res del dia que seria entrat en llur terra entrò que fos fora de Montpestleer, que no despesés lo rei de Castella res del seu, ne persona qui ab ell fos. E així se compli tan abundadament com davant havets oit que fo fet l'altra vegada con estec al regne de València. ${ }^{94}$
\end{abstract}

Curial behaves similarly with the two elderly lausengier who had caused his troubles when they visited him in Paris; he welcomes them and takes them to his hostel: menà'ls-se'ns a posar al seu hostal, e aquí los festejà e honrà molt, e.ls donà tots temps, mentre alli stigueren, tot ço que mester havien, en manera que ells no despenien res. ${ }^{95}$

Sanglier de Vilahir puts a black banner in front of his tent, ab unes letres d'or molts grans qui dehien: 'Ahur'. ${ }^{96}$ In his Crònica, Muntaner refers to how four ships from Sicily arrived to ask King Peter of Aragon for help because Charles of Anjou was besieging Messina. The knights and citizens that disembark from the ships vengren tots vestits de negre e ab les veles negres e ab senyeres negres ${ }^{97}$ to ask 'mercè'; when the king grants them his help, they shout Aür! Aür!, the same word that the Moors cry out when they see the galleys of Corral Lança: los sarraïns qui les veeren, que ja n'havien haüda llengua, cridaren en llur sarraïnesc:-Aür! Aür! ${ }^{98}$

Both texts also share the way they describe a longed for presence. In Muntaner's Crònica, while the king is awaited in Sicily, e així, ab aquell guany tornà-se'n en Sicília, on tots los soldaders, així de cavall con de peu, l'esperaven així com los jueus fan Messies; ${ }^{99}$ for their part, the people who wait for Curial in the tournament in Santa María

93. "what has a pence that they did not spend, nor anyone who was with him". Muntaner, Ramon. Crònica...: I, 36.

94. "And said lord James King of Aragon and the princes had great pleasure and they wondered the way for introducing food and whatever needed into the land till Montpellier. It was so well organized that no lord was ever as well supplied with all his companions as he was; and about the meat to need in the land until Montpelier, he ordered that the king of Castile spent nothing from his own nor anyone who was with him. It was done so faithful, that it was repetead another time when the king visited the Kingdom of Valencia". Muntaner, Ramon. Crònica.... I, 49-50.

95. "ordered them to be put up in his hostal, to regale and honour them here very much, and gave them all time, while they were there, everything they had need of, so that they spent nothing". Curial e Güelfa...: II, 213.

96. "with very big gold letters that said: 'Ahur'". Curial e Güelfa...: II, 221.

97. "all came dressed in black with black sails and black flags". Muntaner, Ramon. Crònica...: I, 94.

98. "the Saracens who saw them, which language it was heard before, shouted in there Saracen tongue: -Hurray! Hurray!". Muntaner, Ramon. Crònica.... I, 46.

99. "and so, with that win they returned to Sicily, where all the soldiery, both horse and foot, awaited him like the Jews await the Messiah". Muntaner, Ramon. Crónica...: II, 62. 
del Puig, Desijaven tots la venguda de Curial, pensant que aquell defendria lo restell, mas vanament lo speraven; decebuts eren com són los jueus del sperar Messies. ${ }^{100}$

The account of the Sicilian campaign in the Crònica mentions in different occasions the Duke of Ostelric (qui és un dels majors barons d'Alemanya), ${ }^{101}$ Ramon Folc de Cardona, Blascó d'Alagó, Joan Eiximinis d'Urrea, ${ }^{102}$ all of them characters that also appear in Curial. ${ }^{103}$ It also mentions the Greek city of Arta, ${ }^{104}$ famous for a bridge, the foundations of which, according to a popular a legend, were secured thanks to the sacrifice of the wife of the master of work. Milà i Fontanals knew this legend, ${ }^{105}$ which might have inspired him to give the Güelfa's maiden her first name before being called Festa, in an evident gesture to Tirant's Plaer-de-ma vida.

But perhaps the most relevant loan regarding names is the one of the Genoese corsair who attacks the merchant galley that takes Curial from Genoa to Alexandria: Un cossari genovès, lo qual Ambrosino de Spindola havia nom, hach sentiment Curial ésser molt rich, e per cobdícia d'aquella roberia, pensant que ab poch treball la hauria, mesa primeramente a punt una galera que tenia, de Portvendres partí; ${ }^{106}$ in some other occasions, he is also called 'Ambròsio de Spíndola'. The name is a funny cross between General Ambrosio de Spínola (1569-1630) and a character cited by Muntaner:

Que dementre que la companya fo partida de Gal-lípol per anar sobre los alans, l'emperador ho sabé; e fo ventura que en aquella saó vengren divuit galees de genoveses, de què era capità ser Antonio Spindola, e era vengut de Gènova en Costastinoble per menar en Llombardia lo fill menor de l'emperador per ésser marqués de Montferrat. ${ }^{107}$

The great Spanish general, of Genoese origin and governor of the Duchy of Milan, appears in the novel I promessi sposi by Manzoni, which Milà i Fontanals

100. "They all awaited the arrival of Curial, thinking that he would defend the castle, and they awaited him in vain; disappointed were they, like the Jews are of waiting for the Messiah". Curial e Güelfa...: III, 235.

101. "who is one of the greatest barons in Germany". Muntaner, Ramon. Crònica...: II, 184, $200,204$.

102. The last two knights attend the tournament in Melun: l'altre ha nom don Blasco d'Alagó, e l'altre ha nom don Johan Ximenes de Urrea (Curial e Güelfa...: II, 82). For his part, Ramon Folch de Cardona, the ambassador of the king of Aragon to the court of the Moorish king, intervenes in the episode of Curial fighting the lion (Curial e Güelfa ...: III, 153-157) and recognises Curial in Melun.

103. Muntaner, Ramon. Crònica...: II, 55, 151.

104. Muntaner, Ramon. Crònica...: II, 122, 152.

105. He summarises the legend in the version wrote by Vretro. Milà i Fontanans, Manuel. "Cuentos y poemas de Grecia Moderna por M. Vretro", Obras completas. Opúsculos literarios. Primera serie, ed. Marcelino Menéndez Pelayo. Barcelona: Álvaro Verdaguer, 1892: IV, 581-584.

106. “A Genoese corsair, whose name was Ambrosino de Spíndola, suspected that Curial could be very rich, and for greed of this robbery, thinking that with little work hew would have it, first prepared a galley that go away from Portvendres". Curial e Güelfa...: III-23-24.

107. "In a meanwhile that the company left Gallipoli to go against the Alans, the emperor knew it; and in this context eighteen Genoese galleys came, captained by Antonio Spíndola, and he came from Genoa to Constantinople to take to Lombardy the younger son of the emperor to be Marquis of Montferrat". Muntaner, Ramon. Crònica...: II, 99. 
greatly admired. Curial mixes the two names, Antonio Spíndola and Ambrosio de Spínola; with the same background: Lombardy, Montferrat.

To finish this section about borrowings from Muntaner in Curial, I refer to the mention of the Knight de la Cota mal tallada ("of the badly-made dress"). After one of his frequent Qué us en diré? ("What can I say to you about this?"), the pet phrase that also appears in Curial and many other texts (from Tristan en prose to Petit Jehan de Saintré), Muntaner praises the work of the king and compares it with that of the great heroes of the knightly world, citing the aforementioned knight: que Galeàs, ne Tristany, ne Llancelot, ne Galvany, ne Boors, ne Palamides, ne Perceval lo Galois, ne el Cavaller ab la Cota mal tallada. ${ }^{108}$ At the end of Viatge del vescompte Ramon de Perellós $i$ de Roda fet al Purgatori nomenat de Sant Patrici, Ramon de Perellós also mentions him: ... arribí al port de Davre, on vi lo cap de Galvany, car aquí morí e així mateix la cota mal tallada car així s'apellava aquell cavaller que la portava. ${ }^{109}$

About the Arthurian Knight of the Badly-fitting Coat, Carlos Alvar says: Keu acuña su sobrenombre tras presentarse el caballero en la corte de Arturo cubierto con la túnica, llena de jirones, que llevaba su padre cuando fue asesinado, prometiendo no quitársela hasta haber vengado esa muerte. ${ }^{110}$ Tristan en prose begins with Lancelot going after the Knight of the Badly-fitting Coat and encountering his first adventures: Or dist li contes que quant Lanselos se fu partis de la damoisele ki a lui estoit venue de par monsigneur Tristan, ensi com je vous ai conté, il se mist tout maintenant a la voie aprés celui a la Cote Mautaillie. ${ }^{111}$

This badly fitting coat is always associated with its tragic origins; conversely, Curial refers to it jokingly. In an episode that imitates another from Tirant lo Blanc (an essential book in the creation of Curial that keeps appearing in episodes and details), Güelfa hands Curial a shirt to wear over his armour, as Carmesina does with Tirant. There is an important difference, however: the embroidery done by Güelfa and the abbess, axi per los pits com per les espatles de alt a baix, creus de sant Jordi, e semblantment per les mànegues. Melchior de Pando takes it to the young knight, who is going to confront Boca de Far: E tantost s'armà e assajà's l'alcandora, e, obrint-la en certes parts, feren tant que li vengué bé, jatsia que en los pits ne en les espatles no li cobria sinó fort poch, de què ell no curava gens. ${ }^{112}$

108. “what nor Galeàs, nor Tristan, nor Lancelot, nor Galvany, nor Bors, nor Palamides, nor Percival the Gallic, not the Knight with the badly-fitting coat". Muntaner, Ramon. Crònica...: I, 216.

109. "arrived at the port of Davre, where the saw the head of Galvany, who he died there and also the badly cut coat and that defined the knight who wore it". Perellós, Ramon de. "Viatge del vescomte Ramon de Perellós i de Roda fet al Purgatori nomenat de Sant Patrici", Novel-les amoroses $i$ morals, ed. Arseni Pacheco, August Bover i Font. Barcelona: Edicions 62, 1982: 52.

110. "Keu coined his nickname after the knight arrived in Arthur's court covered with the tunic, all tattered, that his father had been wearing when he was murdered, swearing not to take it off until he had avenged his death". Alvar, Carlos. El rey Arturo y su mundo. Diccionario de mitología artúrica. Madrid: Alianza Tres, 1991: 65.

111. "It was said that when Lancelot went away, the maiden who was with him by order of Sir Tristan, acording I explained, followed him inmediately to the Badly-cut coat". Le roman de Tristan en prose, ed. Philippe Ménard. Genoa: Droz, 1987: I, 63.

112. "thus on the chest and the back from the top to the bottom, crosses of Saint George, and similarly on the sleeves"; "And when he armed and put the shirt, this was open by different sides till he wore well, 
The effect it thus achieves is hilarious: Per què, muntant a cavall, en cavalls molt forts $e$ valerosos, començaren a anar sots un estandart blanch ab creu vermella e tals paraments; mas tothom reya de la cota d'armes de Curial, veent que era camisa de dona. ${ }^{113}$ And when Curial realizes the general merriment, he says: Ara pusch yo ésser apellat lo donzell de la cota mal tallada. ${ }^{114}$

Humour is a constant feature of Curial; in this case, the nickname of an Arthurian knight is parodied in the same way as Cervantes made fun of all things related to errant knights in Quijote. His parody again reveals the writer of the historical novel, the admirer of Cervantes' irony and... of Walter Scott.

In addition to the aforementioned books, we also find other sources in Curial's text, from the rare Latin writer Fulgentius to the famous Verses on the death of Don Rodrigo Manrique, his Father by Jorge Manrique. All these texts are mixed in a process of rewriting, as Lola Badia and Jaume Torró note in their critical edition, in which they compare Curial's prose with Tirant's: l'Anònim reescriu de dalt a baix els estimuls literaris presos de les fonts [...] en comptes de reproduir parcialmente mots, frases $i$ motius en una xarxa intertextual no mancada de'incongruències, como fa Martorell. ${ }^{115}$ If the 'anonymous' writer can do so, it is because he is not a $15^{\text {th }}$ century author, but a $19^{\text {th }}$ century writer of a historical, Gothic novel.

\section{From Fulgentius' Mythologies to Alfonso de la Torre's Visión deleitable, with elements of Enrique de Villena's Glosas and Jorge Manrique's Verses}

In Curial, three of the four horses of the Sun are named after the names Fulgentius gave them in book I of his Mythologies: Erythraeus, Actaeon, Lampus, and Philogeus:

Huic quoque quadrigam scribunt illam ob causam, quod aut quadripertitis temporum uarietatibus anni circulum peragat aut quod quadrifido limite diei metiatur spatium; unde et ipsis equis condigna huic nomina posuerunt, id est Erytreus, Acteon, Lampus et Filogeus. Erytreus Grece rubeus dicitur quod a matutino prosiliens limine rubicundus exurgat, Acteon splendens dicitur quod tertiae horae metis uehemens insistens lucidior fulgeat, Lampus uero ardens dum ad umbilicum diei centratum conscenderit circulum, Filogeus Grece terram amans dicitur quod horae nonae procliuior uergens occasibus pronus incumbat. ${ }^{116}$

although in front and in the shoulders the dress lacked, which did not worry to him". Curial e Güelfa...: I, 168 .

113. "So, on horseback, on very strong and courageous horses, they began to go under a white standard with a red cross and such kind of decorations; moreover everyone laughed at Curial's coat of arms, seeing that if was a woman's blouse". Curial e Güelfa...: I, 174.

114. "So now I could be called the maiden of the badly-cut coat". Curial e Güelfa...: I, 176.

115. "Anonymous completely rewrites the literary stimuli taken from the sources [...] instead of partially reproducing words, phrases and motifs in an intertextual network not lacking in incongruences, as Martorell does". Badia, Lola; Torró, Jaume. "Introducció...": 105.

116. "And if a chariot is also assigned, it's either because it accomplishes its annual revolution sharing the four distinct seasons, because it divides the course of the day into four quarters. This is also his horses 
This is how they appear in Curial: ... e lo sol ab lo seu carro de quatre rodes tirat per aquells quatre cavalls, ço és, Titan, Etheus, Lampaus e Philogeus, venir fort yvarçosament. ${ }^{117}$ Later on, we find the division according to their function, again as in Fulgentius' book:

Com lo dia ja declinàs, e lo sol, menaçat per les tenebres qui ja s'aparellaven de venir, cuytàs los seus cavalls, dels quals lexats cansats los tres, ço és, Titan, Etheus e Lampaus, tirat solamente per Philogeus, desemparades més de les tres parts del dia, ab major velocitat que dir no.s pot, fugís vers lo regne d'Espèria. ${ }^{118}$

The difference with Fulgentius is in the name Titan, which sometimes designates the Sun, as Ovid does at the beginning of his Metamorphoses: Nullus adhuc mundo praebebat lumina. ${ }^{119}$ Even more significant is the coincidence of the name Philogeus, one more example of the parodic tone of Curial: instead of having the four houses separately related to a part of the day, a quadriga is being pulled by only one horse while the others, tired, refuse to work.

This coincidence is not the only passage that indicates a reading of Fulgentius, cited in Curial at the beginning of the third book, E quant al integument d'aquesta faula, diu Fulgenci que nou Muses són dites nou consonàncies de la veu humana, e les nou Pièrides nou dissonàncies, ${ }^{120}$ which is not exact, as Fulgentius, in the prologue of his work, identifies the Pierides with the Muses, calling himself a "rude disciple of the Pierides" (Fulgenti, rudis accola Pieridum) and addressing the prologue to Calliope.

themselves were given names corresponding to these stages, namely Erythraeus, Actaeon, Lampus, and Philogeus. Erythraeus in Greek means red, because he gets up every red gushing in the morning line; Actaeon means shining, because at the end of the third hour, full of intensity it radiates a brighter light; about Lampus, the flamboyant, when its curve reaches the midpoint of the day; Philogeus, in Greek, means loving the land, because at the ninth hour, inclining in a more pronounced way, it comes down to lie". The editors point out that the name: Philogée n'apparaît nulle part ailleurs ("Philogeus has never been any where"). Fulgence. Mythologies, trans. and ed. Étienne Wolff, Philippe Dain. Villeneuve d'Ascq: Presses Universitaires du Septentrion, 2013: 64-65. The French version given by these editors: Et si on lui attribue également un quadrige, c'est soit parce qu'il accomplit sa révolution annuelle en la partageant en quatre saisons distinctes, soit parce qu'il divise le parcours de la journée en quatre quartiers. C'est aussi pourquoi on a donné à ses chevaux eux-mêmes des noms correspondant à ces étapes, à savoir Érytraeus, Actéon, Lampus et Philogée. Érytraeus, en grec, veut dire rouge, parece qu'il se lève tout rouge en jaillissant sur le seuil du matin; Actéon veut dire resplendissant, parce qu'au terme de la troisième heure, plein d'intensité il rayonne d'une lumière plus éclatante; quant à Lampus, c'est le flamboyant, lorsque dans sa courbe il est parvenu au point médian de la journée; Philogée, en grec, veut dire qui aime la terre, parce que, à la neuvième heure, s'inclinant d'une manière plus prononcée, il descend pur se coucher.

117. "and alone with his four-wheeled cart pulled by these four horses, these being, Titan, Erythraeus, Lampus and Philogeus, he could came very fast". Curial e Güelfa.... III, 80-81.

118. "As the day already fades, and the sun threatened by the darkness that already paired to come, he looked after the horses, of which the three steeds tired, that is, Titan, Etheus and Lampaus, being pulled alone by Philogeus, helpless more than three parts of the day, as fast as possible, fleeing toward the kingdom of Esperia". Curial e Güelfa...: III, 249-250.

119. Ovid. Metamorphoses, in fifteen books, ed. John Minellius. Dublin: P. Wogan, 1815: 2.

120. "As for the integument of this fable, Fulgentius says nine Muses are these resonances of the human voice, and nine Pierides, nine dissonances". Curial e Güelfa...: III, 6. 
But the text of Curial takes a loan from Fulgentius' Fabula de nomen Musis. The Latin author adds Apollo to the nine Muses, as ten is the number of elements in the human voice: Huic etiam Apollini nouem deputant Musas ipsumque decimum Musis adiciunt illa uidelicet causa, quod humanae uocis decem sint modulamina: unde et cum decacorda Apollo pingitur cithara. Sed et lex diuina decadordum dicit psalterium. ${ }^{121}$ Then, he describes the voice emissions in a curious description that surely thrilled the philologist Milà, who copied it in Curial:

Fit ergo uox quattuor dentibus, id est e contra positis, ad quos lingua percutit et quibus si unus minus fuerit sibilum potius quam uocem reddat necesse est. Duo labia uelut cimbala uerborum commoda modulantia, lingua ut plectrum quae curuamine quodam uocalem format spiritum, palatum cuius concauitas profert sonum, gutturis fistula quae tereti meatum spiritalem praebet excursu et pulmo qui uelut aerius follis concepta reddit ac reuocat. Habes ergo nouem Musarum uel Apollinis ipsius redditam rationem. ${ }^{122}$

$F a ' s$, donques, la veu, per quatre dents contraposades, les quals la lengua fér, de les quals si alguna defall ha defalliment en la veu; dos labis, dues cathacimbales, als quals la lengua plega, e com se encorba forma un vocal spirit en la concavitat del paladar o de la boca, qui per lo cami de gola corre com per flauta; los leus o polmons, axí con manxes, envíen lo vent, e despuys que és enviat lo revoquen e cobren. E aquests nou instruments són dits nou Muses, a les quals és ajustat Appolló, pero ço com deu són les veus de tota melodia, e poch valdrien los instruments si no fos instrumentador. E açò quant al cantar. ${ }^{123}$

Next, he returns to the ten-stringed harp cited by Fulgentius: Axí mateix Appol·ló se pinta ab decacordi, que vol dir instrument ab deu cordes concordants o deu veu consonants, e finalmente cítara. E així saltiri és dit decacordi, quasi deu cordes consonants, segons és dit. ${ }^{124}$

121. Fulgence. Mythologies...: 66.

122. "The vocal expression is therefore with four teeth, those that face the tongue and against which it strikes; if it finds one less, the tongue inevitably produces a hissing sound rather than a vocal sound. The two lips are like cymbals that give a measure of the flexibility of the words; the tongue as a plectrum and its curvature rules the breath of the voice: the concave shape of the palate emits the sound; the pipe of the throat offers, by its rounded end, a passage for breathing; and the lungs, like a bellows filled with air, expire and inspire their content. That is the explanation of the nine Muses and Apollo himself". The French version by the editors: L'expression vocale se fait donc par quatre dents, celles qui font face à la langue et contre lesquelles elle vient frapper; s'il s'en trouve une de moins, la langue produira inévitablement un sifflement plutôt qu'une sonorité vocale. Les deux lèvres sont comme des cymbales qui donnent une mesure à la souplesse des mots; la langue est comme un plectre et sa courbure règle le souffle de la voix: la forme concave du palais émet le son; le conduit qu'est la gorge offre, par son issue arrondie, un passage à la respiration; et les poumons, comme un soufflet rempli d'air, expirent et inspirent leur contenu. Voilà donc l'explication des neuf Muses et d'Apollon lui-même. Fulgence. Mythologies...: 67.

123. "He reach to express the voice with the tongue throughout four opposed teeth, which, in case one of them fall, it is noticed in the voice; two lips as two kettledrum, where the tongue stops and as they curve form a vocal spirit in the concavity of the palate or the mouth, which during the way to the neck, the sound slights or strongs run like a flute, similar to bellows that puch the air, and after sending the air, the recover it. And these nine instruments are called nine Muses, which Apollo is closed, but in any case, at it is due, the voices are absolutelly harmonious, and few important would has the instruments without the player. And all this fong singing". Curial e Güelfa...: III, 7.

124. "Apollo is likewise also painted with decachord, which means an instrument with ten concordant strings or ten consonants voices, and finally zither. And so said psaltery is called decachord, almost ten consonants strings, as is said". Curial e Güelfa...: III, 7. 
After a citation from Psalms 92, 4 (Vulgata 91, 4), he returns to Fulgentius and summarises the list and explanation about the nine Muses. About the first, the text of Curial notes, Item les dites Muses en altra manera són all-legorizades: que la primera Musa sí.s appellada Clio, que és interpretada gloriosa dea, o cogitació gloriosa de cercar o cogitar sciència; 'cleos' en grech, en latí 'fama', la qual segueix la sciència. ${ }^{125}$

Fulgentius' text clarifies this allegory:

Nos uero nouem Musas doctrinae atque scientiae dicimus modos, hoc est: prima Clio quasi cogitatio prima discendi -cleos enim Grece fama dicitur [...] et quoniam nullus scientiam quaerit nisi in qua famae suae protelet dignitatem, ob hanc rem prima Clio appellata est, ide est cogitatio quaerendae scientiae. ${ }^{126}$

So it continues with the other eight Muses and the Pierides, in the tradition of Ovid: Tantost les dites Pièrides foren per los déus convertides en piques, que en común lenguatge cathalà són dites garces, e són ocells garruladors, e aprenen parlar en totes lengües ço que $\cdot l s$ mostren, emperò no saben ni entenen ço que dien. ${ }^{127}$

He takes the word piques from Canto I of the Divine Comedy's Purgatorio: seguitando il mio canto con quel sòno / di cui le Piche misere sentiro / lo colpo tal, che disperar perdono. ${ }^{128}$ This piques (picae in Latin, more similar to Pierides) mean 'magpie' in Catalan. Although he has followed Fulgentius' text, he now provides an explanation from Ovid (Metamorphoses, V) in which the Muses are an allegory of the degrees of knowledge. ${ }^{129}$

A little before, Fulgentius (Mitologiae I, 8) had talked about the Fabula de Fatis, Cloto, Laquesis and Atropos:

Tria etiam ipso Plutoni destinant fata: quarum prima Cloto, secunda Lacesis, tertia Atropos -clitos enim Grece euocatio dicitur, Lacesis uero sors nuncupatur, Atropos quoque sine ordine

125. "Also,said Muses are allegorised in another way: the first Muse is called Clio, which is interpreted as glorious goddess, or glorious cogitation to seek or cogitate upon science; 'cleos' in Greek, in Latin, 'fame', which follows science". Curial e Güelfa...: III, 8.

126. "For us, the nine Muses correspond to the degree of education and knowledge; and the first is Clio, that is the first purpose of study; indeed, cleos, in Greek, means rumor [followed by two quotation from Homer]; and, since nobody seeks knowledge that will enable them to extend the magnificence of her reputation, for this reason, the first was named Clio, that is to say the intention to pursue knowledge". From the French version of the editors: Por nous, les neuf Muses correspondent aux degrés de l'éducation et du savoir; ainsi la première, c'est Clio, autrement dit le premier dessein de l'étude; en effet, cleos, en grec, signifie rumeur [followed by two quotation from Homer]; et, puisque personne ne recherche un savoir qui ne lui permette de prolonger la magnificence de sa réputation, pour cette raison, la première fut nommée Clio, c'est-a-dire le dessein de rechercher le savoir. Fulgence. Mythologies...: 66-67.

127. "Inmediatelly the said Pierides were converted by the gods into piques, that in common Catalan are called 'graces' (magpies), and they are garrulous birds, and learn to speak in all languages they are shown, but they do not know nor understand what they are saying". Curial e Güelfa...: III, 6.

128. "Accompanying my song with that sound / of which the magpies felt miserable / hit him so hard, that he despaired of pardon". Alighieri, Dante. "Divina Commedia", Tutte le opere, ed. Italo Borzi, Giovanni Fallani, Nicola Maggi, Silvio Zennaro. Rome: Grandi Tascabili Economici-Newton Compton, $2005: 234$ (lines 10-12).

129. Curial e Güelfa...: III, 9. 
dicitur; hoc uidelicet sentire uolentes quod prima sit natiuitatis euocatio, secunda uitae sors, quemadmodum quis uiuere possit, tertia mortis conditio quae sine lege uenit. ${ }^{130}$

This explanation may serve to understand the Duke of Bavaria's strange choice of names in calling his daughters Cloto and Laquesis, the names of the Parcae. However, we should still add another text to see Curial's erudite weaving better: Traducción y glosas de la Eneida, libros I-III ${ }^{131}$ by Enrique de Villena, ${ }^{132}$ an author that Milà i Fontanals had read with care:

Dixeron los poethas que tres fadas eran que fadavan todos los omes en sus nasçimientos, a las
cuales llamaron Clotho, Lacchesis e Antropos; e que Clotho trae la rueca e Lacchesis tirava
el filo e ordía la tela e Antropos la cortava. Llamáronles Parcas, es a saber perdonaderas,
por contrario, porque a alguno non perdonavan, ansí como al vinagre dizen vino dulçe; e
quiriendo por estas entender los tres tiempos, pasado, presente e porvenir, que traen la serie
de las causas, que son los fados de los omes, segúnd ya se declaró en una otra glosa ante
d'esta. E bien dan a entender sus nombres esto que d'ellas es dicho, porque Clotho en griego
quiere dezir "vocaçión", mostrando la entrada de la vida. E Lacchesis en griego quiere dezir
"suerte", que es la suerte de la vida, siquiere la duraçión de aquélla. Antropos en griego
quiere dezir "sin orden", por la condiçión de la muerte, que non viene a çierto tiempo. ${ }^{133}$

130. "It also affects the same Pluto three Destinies: the first is Clotho, Lachesis the second and third Atropos -in fact, clitos, in Greek, means call, Lachesis means fate and Atropos mean no rules; by this we obviously want to make it understood that the first is the call to be born, the second the fate of life, how everyone can live, the third, the reality of death that comes without being bound by any law". From the French version of the editors: On affecte également au même Pluton les trois Destinées: la première est Clotho, la deuxième Lachésis et la troisième Atropos -en effet, clitos, en grec, veut dire appel, Lachésis désigne le sort et Atropos veut dire sans règle; par là on veut évidemment faire comprendre que la première est l'appel à naître, la deuxième le sort de la vie, la manière dont chacun peut vivre, la troisième la réalité de la mort qui arrive sans être tenue par aucune loi. Fulgence. Mythologies...: 62-63.

131. Villena, Enrique de. Traducción y glosas de la Eneida, libros I-III. Obras completas, II, ed. Pedro Cátedra. Madrid: Biblioteca Castro, 1994: 73.

132. Lola Badia and Jaume Torró note dos errors conjuntius ("two conjunctive mistakes") in Villena's Glosas and in Curial (goddess Obsrea or Opstrea and Dido's lineage refered by Camar); they underscore that és rellevant haver pogut demostrar que l'Anònim usava unes glosses de l'Eneida que comparteixen alguns errors textuals amb les que Villena va fer servir en el seu comentari castellà ("it is rellevant to have demonstrated that the Anonimous used the glosses from the Eneida, which shared textual mistakes with the ones used by Villena in their Castilian coment"), and attribute the fact to his education in l'ambient cultural de les corts dels Trastàmara de les primeres dècades del segle XV ("the cultural atmosphere into the Royal Courts of Trastamara Dinasty during the first decades of the $15^{\text {th }}$ century"). Badia, Lola; Torró, Jaume. "Introducció...": 84-85. Contrary to what the scholars oppinion, it is not a common source what links the two works, but the reading of Villena's Glosas by Milà i Fontanals. The numerous medieval sources from different literatures that appear in Curial only make sense from the perspective of the scholar's vast erudition.

133. "The poets said that the three fairies wre infront all the men at their birth, who they called Clotho, Lacchesis and Antropos; and that Clotho brought the spinning wheel and Lacchesis spun the thread and wove the cloth and Antropos cut it. They was called Parcas, that is, those who forgive; but, in contrast, they did not forget someone, such as they said sweet wine to the vinegar, and whishing to understand the three times (past, present and future) that organized the causes and fate of the man, according it is said above in another glosse. Their names allow understand what is said about them, because in Greek Clotho means 'vocation', showing the entrance of the live. And Lacchesis in Greek means 'luck', which is the luck of life, according its duration. Antropos in Greek means 'without order', for the condition 
Later on, in the gloss of book II, referring to Pryam's death, he insists:

...que fue por terminación de los fados, es a saber por acarreo de las costillaçiones celestiales, que causan aquellas tres partes del tiempo, es a saber prinçipiante, mediante e finiente, a quien dixeron los poetas fadas, que fadavan los ombres, nombradas por ellos Clotho, Lachesis e Antropos. ${ }^{134}$

In Curial, Antropos does not take the usual spelling, 'Atropos'; this is Melchior de Pando talking to the hero: Curial, aquesta doncella pot haver nom Laquesis, mas ella és Àntropos, certament, e axí ho provarets per temps. ${ }^{135}$ And Fortune, talking to Güelfa in her dreams: e sinó tement que Àntropos lo'm tragués d'entre mans. ${ }^{136}$ In the same sense, we should understand Curial's expression when talking to Calliope: $O$, egrègia senyora! ¿E quals fades me fadaren que yo tanta honor reebés, que nou germanes, filles del major del déus mortals, vengessen a mi e visitassen aquest sepulcre de ignorància? ${ }^{137}$ Or the presence of Venus' mother, Dionio, ${ }^{138}$ 'Dione' in Curial, ${ }^{139}$ that of the leedores so present in his glosses of Virgil —legidor in Curial - ${ }^{140}$ or the repeated reference to Troyana historia by Guido de Columnis, Historia Fiorita by Armannino, the celebrated Dictis and Dares, even the surprising guay! from Curial: ;Guay de mi, que yo ací no venia per consell!; ${ }^{141}$ iE, guay, que non es de fiar en los dioses cuando son forçados! ${ }^{142}$ Also surprising is the desusada mà that Curial alargà al plat to eat ${ }^{143}$ which Villena uses in his letter to the king of Navarre, to whom he offers his work: por cuya contemplacçión e mandado se atrevió mi desusada mano tractar la péñola escriviente la virgiliana doctrina en la Eneida contenida. ${ }^{144}$

After spending seven years imprisoned in Africa, being now rich after obtaining the treasure of Camar's father and regaining his ladyship's favour, Curial leaves for a time of dissolution in France: se donà a viure mollament e laciva, como si fos arquebisbe

of death, which arrive in a unespected time". Villena, Enrique de. Traducción y glosas de la Eneida, libros $I-I I I \ldots:$ : 73 .

134. "which was termination of the fates, that is by combination of celestial constellations, causing those three parts of time, namely beginning, middle and finishing, that the poet fadas said, who fate give the shadows named by them Clotho, Lachesis and Antropos". Villena, Enrique de. Traducción y glosas de la Eneida...: 486.

135. "Curial, this maiden could be named Laquesis, although she is Àntropos, certainly, and it can be tested for long times". Curial e Güelfa...: I, 109.

136. "and if not fearing that Àntropos removed it from my hands". Curial e Güelfa...: III, 223.

137. “Oh, distinguished Madam! And what fairs will enchante to me, in order I can receive so big honour? That nine sisters, daughters of the greatest of the mortal gods, came to me and visited this sepulchre of ignorance?". Curial e Güelfa...: III, 78.

138. Villena, Enrique de. Traducción y glosas de la Eneida...: 614.

139. Curial e Güelfa...: III, 58 and following.

140. Curial e Güelfa...: II, 247.

141. "Be careful of me, because I did not go here for advice!". Curial e Güelfa...: III, 70.

142. "Be careful, that we cannot trust in the gods when thet are forced!". Villena, Enrique de. Traducción y glosas de la Eneida...: 414.

143. "barely used hand"; "he approximated the plate". Curial e Güelfa...: I, 99.

144. "for whose contemplation and order, my vacant hand dared works on the writing pen of the Virgilian doctrine contained in the Aeneid". Villena, Enrique de. Traducción y glosas de la Eneida...: 5. 
o gran prelat, no recordant-se ésser cavaller ne home de sciència ${ }^{145}$ (we can perceive the author's delight in this satirical reference to the Church's authorities). Indulging in vices (greed, lust), it is not surprising that one night, Bacchus (not precisely a déu de sciència - "God of science" — as the narrator concedes) appears in his dreams; but he will also have a visión deleitable ("delightful vision") of the seven liberal arts as drawn in Alfonso de la Torre's work.

As this author notes, la lumbre intellectual, la qual es llamada vision; ; ${ }^{146}$ next to this god, Curial sees the seven queens; in Visión deleitable these are seven maidens. The first one holds in her right hand a título escripto de letras latinas, las quales dezían en esta manera: 'Vox litterata et articulata debito modo pronunciata'. E en la siniestra mano tenía una palmatoria con açotes. A muy gracioso ("very cute") little kid gets close to her como que veniese fuyendo al abrigo de su madre e se acogió a la donzella. El qual niño avía nombre entendimiento; ${ }^{147}$ she tells him:

El mi ofiçio es tratar de la disçiplina et artefiçio de las letras; conviene a saber de las letras latinas et de las partes de la oraçión, de las sílabas, de los pies, de los açentos, de la ortographía, de la ethimología, de la diasintástica, del barbarismo, del soliçismo et de los otros viçios del metaplasmo, del tema, del tiempo, de la fábula, de la prosa, de la ystoria. ${ }^{148}$

In Curial, the vision of the seven arts is much shorter, less allegorical and characterised by the irony that permeates the whole story. As an example, let us see how the first queen, Grammar, appears surrounded by little children (and not, as in Alfonso de la Torre, talking to the nice little children of Knowledge):

Estaven davant aquell déu, a la part emperò esquerra, una reyna, ab aquella cara jove e fadrina e una corona al cap no molt preciosa, circuyda de infinits minyons, qui uns legien, altres ploraven; e tenia la dita reyna en la man dreta unes correjades, e en la squerra un cantell de pa. Stàvan davant aquesta quatre donzelles molt belles, les quals los seus noms propris tenien brodats als pits, e per aquelles letres Curial sabé lo nom de cada una d'elles, ço és: Ortografia, Ethimologia, Diassintàstica e Prosídia. ${ }^{149}$

\footnotetext{
145. "they gave smoothly and lascivious living, as if he was a great prelate archbishop or not remembering he was a knight or science's man". Curial e Güelfa...: III, 173.

146. "the intellectual fire, which is called vision". Torre, Alfonso de la. Visión deleitable. Toulouse: Juan Parix and Esteban Clebat, 1489: f. 6v (facsimile, Madrid: Espasa-Calpe, 1983). The work was published in a Catalan translation in 1484 and in Spanish in 1485.

147. "title written in Latin letters, which said in this way: Vox litterata et articulata debito modo pronunciata. And in the left hand, it was done evident scourges"; "like he ran away looking for being harbouring by his mother, and he took the protection of the maiden. And this boy had the name of Knowledge". Torre, Alfonso de la. Visión deleitable...: ff. 4-5v.

148. "My trade is to try to discipline and artifice of letters; to know the Latin letters and the parts of speech, syllables, feet, accents, the spelling, the etymology, the syntax, barbarism, the solecism and other vices of the metaplasm, the theme, time, fable, prose, the history". Torre, Alfonso de la. Visión deleitable...: ff. $4-5 \mathrm{v}$.

149. "They stood before that God, on the left however, a queen, and with that face of a young maiden and a not very beautiful crown on her head, surounded by countless boys, who some read, others wept; and the queen said had belts in her right hand, and on the left, a piece of bread. Before her, four very beautiful maidens, with their names were embroidered on their own breasts, and for whose letters Curial
} 
This cantell de pa ("a bit of bread") that she is holding takes us to another text, Libre de Fortuna e Prudència by Bernat Metge, in which the old man tricks her into getting on the ship en l'una ma tench un anap / en l'altra un cantelh de pa. ${ }^{150}$ Children who read are thus rewarded, and those who cry suffer correjades ("blows with a belt").

The next queen in Visión - la señora de aquella tierra- is Logic: en la mano derecha tenía un manipulo de flores et un título en letras griegas que dezían verum et falsum. En la siniestra tenía un muy ponçoñoso escurpión. ${ }^{151}$ In Curial's vision, the queen no podia estar segura; e tenia dues serps, ó és, una en cascuna mà, les quals contínuament se volien mordre; in front of her there were three maidens with their names embroidered in their bosoms: 'Probabilis, Demostrativa e Sophística'..152 In Visión deleitable, Logic teaches Knowledge to argue by means of syllogisms.

The third queen in Vision, Rhetoric, is a source of more coincidences:

Era infinitamente muy más aparente ansí en el gesto de la cara e façiones et proporciones de la propria persona como en el sumpto ert preçio de las vestiduras a primera faz [...]. A las vezes fazia un gesto en tanto exçeso de alegría [...]. En la mano diestra tenía un añafil. En la siniestra tenía un libro cerrado. ${ }^{153}$

Painted around the room, Knowledge sees los tres géneros de las causas: deliberativo, demostrativo, judicial. ${ }^{154}$

The third queen in Curial's vision is dressed de vàries colors vestida, emperò molt ricamente avillada; e estava tan alegra cantant, que açò era una gran maravella. ${ }^{155} \mathrm{Her}$ three maidens were called 'Judicialis, Demostrativa, Deliberativa'. ${ }^{156}$

The fourth queen tenía una taula blanca davant si, and the maidens attending had the names 'Par, Dispar'. Without Visión deleitable as a guide, it is not easy to interpret this fourth figure, Arisméthica, who en la mano diestra tenía un grifio de fierro; en la siniestra una tabla emblanquida. E en somo de las vestiduras tenía unas letras griegas, en

knew the name of each one, that is: Spelling, Ethimology, and Disyntactic and Prosody". Curial e Güelfa...: III, 174 .

150. "in one hand tench a glass / in the other a bit of bread". Metge, Bernat. Obras, ed. Martí de Riquer. Barcelona: Universitat de Barcelona, 1959: 28.

151. "in her right hand she had a bunch of flowers and a title in Greek letters they that said verum et falsum. In the left, she had a very poisonous scorpion". Torre, Alfonso de la. Visión deleitable...: ff. 7v-8.

152. "could not be sure; and had two snakes, or one in each hand, who continually wanted to bite". Curial e Güelfa...: III, 175.

153. "It was thus infinitely more apparent gesture face and factions and proportions propria persona as in the question and cost of the garments to first face [...]. Sometimes, she expressed an excess of happiness [...]. In her right hand she had an anaphil. In her left, she had a closed book". Torre, Alfonso de la. Visión deleitable...: ff. 11-12.

154. "the three kinds of causes: deliberative, demonstrative, judicial". Torre, Alfonso de la. Visión deleitable...: f. 13.

155. "dressed in various colors, however very richly dressed; and was so happy singing that this was a great marvel". Curial e Güelfa...: III, 175.

156. Curial e Güelfa...: III, 175. 
las quales decia: Par e impar. ${ }^{157}$ The Toulouse edition that I consulted includes the inscription Par e impar.

The next maiden is Geometry; while in Visión deleitable each maiden is one step closer to the peak of a mountain, in Curial's vision the queens are getting closer to the god Bacchus. In Visión deleitable, en la mano derecha tenía un cordel delgado con una pieça del plomo; en la siniestra un compás muy conçertado, and the maidens tell to Knowledge that el antiquíssimo Tales avía fallado el artificio de medir en lo alto e llano e profundo. ${ }^{158}$ In Curial's vision, the queen tenia un livell en la una mà, e en l'altra un compàs, and her three maidens were called 'Altimetria, Planimetria, Subeumetria'. ${ }^{159}$

The next queen in Curial is Music, although her name is not mentioned and we have to deduce it (in contrast to Visión deleitable, where the allegories are personified with illustrations). About her, the narrator tells us: Sonava uns òrguens e cantava ab tanta dolçor de melodia, which corresponds to the passage from Alfonso de la Torre that reads, E la çélica donzella tenía en la mano una viuela et en la otra mano unos órganos manuales, in which Knowledge is painted over the walls, las tres partes de la música; conviene a saber: la armónica, la orgánica, la métrica, ${ }^{160}$ three aspects that in Curial correspond to the three accompanying maidens: Organico flatu, Armonica voce, Ritmica pulsu, accurate names that reveal an author (as was the case with Milà) who knew about music.

The seventh and last queen, the closest to Bacchus, tenia una spera en la mà e un quadrant als pits. ${ }^{161}$ As stated in Visión deleitable, she is Astrology, who sits on top of the mountain and can open the door of the room where Truth resides. What in Curial reads, havia la vista tan àgil que penetrava e traspassava los cels, corresponds, in Visión, with que ella avía visto en su agudeza de ojos. And her ofiçio era considerar la altura et el movimiento et la quantidad de los çielos et estrellas, ${ }^{162}$ but the explanation in this book is shorter because there is room for the speeches of Truth and other virtues. In Curial, this passage is similar and it closes with two maidens called Motus and Effectus.

The enumerations end with the characters sitting at the feet of the first queen: Priscian, Uguici, Pàpias, Catholicon, Ysidoro, Alexandre e molts altres; Prisciano, Alixandre de Viladei - thus clarifying the possible confusion created by the name Alexandre-

157. "she had a white table in front of her"; "in her right hand she had an iron glyph; in her left, a whitened table. And in the clothes she had some Greek letters, which said: Odd and even". Torre, Alfonso de la. Visión deleitable...: f. 14.

158. "in her right hand, she had a thin cord with a piece of the lead; in the left a compass very good worked"; "the very old Tales had defined the artifice for measuring in height, flat and depth". Torre, Alfonso de la. Visión deleitable...: f. 15v.

159. "had a ruler in one hand, and in the other a compass". Curial e Güelfa...: III, 176.

160. "some organs were playing and singing with such sweetness of melody"; "and the thin maiden had in her hand a vihuela and in the other hand some manual organs"; "the three parts of the music; it is important to know: the harmonic, the organic, the metric". Torre, Alfonso de la. Visión deleitable...: ff. 16-16v.

161. "had a sphere in her hand and a quadrant on her breast". Curial e Güelfa...: III, 176.

162. "had such sharp eyesight that it penetrated and went through the skies"; "that she had seen in her sharpness of eyes"; "trade was to consider the height and the movement and the quantidty of the skies and stars". Torre, Alfonso de la. Visión deleitable...: ff. 17-17v. 
and before them, Oguicio, also appear in Visión deleitable as 'inventors' of the different sciences. Just before listing them, and in a new display of irony, the narrator of Curial says: Detràs d'aquell déu havia tanta gent e de tan diverses partides e de tan stranyes terres, que si no fos que tots parlaven llatí, nulls temps se fóran entesos. ${ }^{163}$ Such a commentary, which does not make sense in an allegorical vision, is understandable in a realistic narration, as in Relaciones de la vida de Marcos de Obregón, which also occurs in the city of Milan, and in which we find people using Latin as a lingua franca: Hallamos alli que habian pasado en otro barco algunas gentes de diversas naciones: franceses, alemanes, italianos y españoles. Y para entendernos, hablamos todos en latín. ${ }^{164}$

In addition to these different readings, which left their traces in Curial, we should note Jorge Manrique's Verses on the death of Don Rodrigo Manrique, his Father (thus from after November 1476); Sanglier, who was once ordained as a Franciscan, reminds us in verse XVI, the one referring to the Princes of Aragon, in his sermon to Curial:

E prech-te que.m digues: ¿què és ço que.t ha sobrat de la multitut de viandes precioses que has menjades, de les dances, de les juntes e dels torneigs que has fets? ¿On són les festes en les quals te est trobat? Mostra-les-me, frare meu. ¿On és lo dia de ir? Mostra'l-me. ¿On és la glòria dels preciosos ornaments? ¿No sabs totes les coses haver fi? ${ }^{165}$

The citation is from the verse that opens with, ¿Qué se hizo el rey don Juan? / Los infantes de Aragón, / ¿qué se hicieron? I ¿Quéfue de tanto galán? / ¿Quéfue de tanta invención / como trajieron? and continues with Las justas y los torneos, / paramentos, bordaduras / $y$ cimeras / ¿fueron sino devaneos? ${ }^{166}$ A bit later, Achilles is referred in the same way as Manrique famously described his father don Rodrigo: Amigo de sus amigos [...] / iQué enemigo de enemigos! ${ }^{167}$ —although amico amicus belongs to a earlier tradition noted by

163. "Hugucio, Papias, Catholicon, Isidore, Alexandre and many others"; "Behind that God there were so many people and so many games and so strange lands, which if not all speak Latin, they would at no time be understood". Curial e Güelfa...: III, 177.

164. "We found that on another boat there had been some people from different nations: French, German, Italian and Spanish. And to understand each other, we all speak Latin". Espinel, Vicente. Relaciones de la vida del escudero Marcos de Obregón. Novela picaresca, ed. Rosa Navarro. Madrid: Biblioteca Castro, 2008: IV, 249.

165. "And pray tell me: what is that which is left over from the multitude of exquisite delicacies that you have eaten, of the dances, of the jousts and the tournaments you have done? Where are the parties you have found yourself in? Show them to me, my good friar. Where is the day of yesterday? Show it to me. Where is the glory of the precious ornaments? Don't you know everything has an end?". Curial e Güelfa...: III, 39.

166. "What came of King John? / Princes of Aragon, / what came of them? / What of so many squires? / What of such much invention / what did they bring?"; "The just and the tournaments, / facings, embroideries / and crests / were but dalliances?". Manrique, Jorge. Poesía, ed. Vicente Beltrán. Barcelona: Crítica, 1993: 158-159 (lines 181-186).

167. "Friend of his friends [...] / What an enemy of enemies!". Manrique, Jorge. Poesía...: 118 (lines 301 , 304). 
Erasmus in his Adagia. ${ }^{168}$ In Curial, the Greek hero is referred to as amich de son amich e enemich de son enemich, ${ }^{169}$ while dancing (les dances) appears in the next verse, ¿Qué se hizo aquel danzar. ${ }^{170}$ Similarly, a reference to the yesterday having passed -on és lo dia de ir? ("where is the day of yesterday?") - comes from the previous verse: vengamos a lo de ayer, / que tan bien es olvidado / como aquello. ${ }^{171}$ The reference to food in this context of Curial should be counted as yet another irony, as it is obvious that food is ephemeral and thus cannot be related to the motive of $u b i$ sunt.

\section{Conclusions}

Curiale Güelfa is not a chivalric novel written in the $15^{\text {th }}$ century. This is manifested both in the irony that the reader keeps gleefully to find at every step as well as in the novel structure. Book three opens with an acknowledgement: lo qual és algun poquet pus intricat que.ls altres primers; ${ }^{172}$ the narrator thus shows knowledge of the whole work as well as its effects on the reader. However, a third element perfectly portrays the author of the work: the fact that he is an erudite scholar who has read vastly, from Muntaner's Crònica to the Novellino, from Paris e Viana to Petit Jehan de Saintré, somebody who knows the troubadours, Rigaut de Berbezilh (whose song he credits) and Raimbaut de Vaqueiras, who has read Fungentius' Mitologiae, Glosas de la Eneida by Enrique de Villena, Visión deleitable by Alfonso de la Torre, Manrique's Verses and Luis Milán's El cortesano. Concordance with these -and other- works reveal that Curial e Güelfa is a composite imitation created by an author... from the $19^{\text {th }}$ century who has read the most outstanding works of Romance literatures (he also imitates Dante, Petrarch or Boccaccio, as the work of other scholars has shown). ${ }^{173}$

The literal citations from these works, the nods to very diverse literary creations (from Spanish works of the Golden Era to Gothic novels by Walter Scott), undoubtedly indicate that the author of Curial e Güelfa was its discoverer: Manuel Milà i Fontanals. Therefore, this erudite creation is, as he said, a mélange de gothique et de renaissance ("a mixing of Gothic and Renaissance"): a Gothic novel in its time (none of the $15^{\text {th }}$ century novels were ever called 'Gothic') and a great work by an author of the Catalan Renaixença. Only an erudite scholar like Milà could have written a novel with such a wide display of readings, the outcome of a hyperelaborated composite imitation. A Napoleonic general who besieged Barcelona with the Fifth Division of the Hundred Thousand Sons of Saint Louis might have inspired

\footnotetext{
168. Erasmus. Adages Iil to Iv100, ed. and trad. Margaret Mann Phillips. Toronto-Buffalo-London: University of Toronto Press, 1982: 250 (I, iii, 17) (Collected Works of Erasmus: 31)

169. "Friend of his friend and enemy of his enemy". Curial e Güelfa...: III, 83-84.

170. “What did that dancer do?". Manrique, Jorge. Poesía...: 112 (line 202).

171. "we come from that of yesterday, / which is well forgotten tan / like that". Manrique, Jorge. Poesía...: 175 (lines 178-180).

172. "which is a bit most complex than the first one". Curial e Güelfa...: III, 13.

173. Badia, Lola; Torró, Jaume. “Introducció...": 59-98.
} 
the name of the main character, Curial ("courtier"), a name that, in addition, fitted the work well, in a nod to another original work from the Renaissance that mixed languages and genres, El cortesano, written by a Valencian author with the same surname, Luis Milán.

No $15^{\text {th }}$-century writer could have access to all the medieval texts that appear in it and whose presence I have shown in my analysis, because only the printing press enabled the spread and thus, the reading, of Italian, Provencal, French, Castilian and Catalan works written in the Middle Ages. Undoubtedly, the presence of works from later than the date assigned to the story in the text of the Curial mean it is impossible to continue to claim that this work was written in the $15^{\text {th }}$ century. Curial e Güelfa is the creation of a great scholar, the finest $19^{\text {th }}$-century peninsular Romanist: Manuel Milà i Fontanals. 